\title{
A new structural interpretation relating NW Libya to the Hun Graben, western Sirt Basin based on a new paleostress inversion
}

\author{
K M ABDUnASER ${ }^{1, *}$ and $\mathrm{K} \mathrm{J}$ W MCCAFFreY ${ }^{2}$ \\ ${ }^{1}$ Libyan Petroleum Institute, PO Box 3461, Tripoli, Libya. \\ ${ }^{2}$ Department of Earth Sciences, Durham University, Durham, DH1 3LE, UK. \\ *Corresponding author.e-mail: k_abdunasser@hotmail.com
}

The present study is based on fault-slip data (striated fault planes with known sense of slip) measured in outcrops in two structural domains located along the Hun Graben, western Sirt Basin (150 fault-slip data) and the Jifarah Basin and Nafusah Uplift, northwest Libya (200 fault-slip data). Pre-existing field data collected in two previous studies were reprocessed using standard inversion methods in MyFault ${ }^{\mathrm{TM}}$ (v. 1.03) stereonet software, produced by Pangaea Scientific Ltd.

The aim of this study was to use paleostress orientations and relative paleostress magnitudes (stress ratios), determined using the reduced stress concept, to test a new understanding of the kinematic characteristics, the relationship between the two areas and the paleostress fields that controlled the evolution of the fault systems responsible for the observed deformation.

Various types of faults (normal faults, sinistral normal faults, dextral normal faults and strike-slip faults) were recorded from outcrops comprised of Mesozoic and Cenozoic sedimentary sequences in which a lineation rake is present on minor structures with displacement ranging from several centimetres to several metres.

Two different domains of a NNE-SSW directed extension regime ranging from $\mathrm{N} 12^{\circ} \mathrm{E}$ to $25^{\circ} \mathrm{E}$ and minor ENE-WSW and WNW-ESE compression were identified in the analysis. The results are remarkably homogeneous at all sites and consistent with progressive collisional coupling of Africa and Europe, being under approximately WNW-ESE reactivated compressional stresses during the Late Eocene-age. The new kinematic and structural conceptual model that has been proposed is a test of the prevailing tectonic models describing the Cenozoic kinematic evolution of the areas. The results show the remarkable influence of basement fabrics of different ages on the subsequent structural development of NW Libya.

\section{Introduction}

One of the most important issues in paleostress inversion studies is the use of fault geometry and kinematic data to reconstruct stress configurations (Angelier 1984, 1989). This is achieved using structural measurements of faults, cutting dated stratigraphical horizons followed by a 'paleostress' (in reality brittle strain) analysis, based on the work pioneered by Angelier $(1984,1989)$ and many others. During the 20th century, geologists sought to understand the origin and evolution of faults, and the tectonic history of faulted regions, by relating fault orientation and slip direction to the state of stress in Earth's crust (Anderson 1951; Price 1966; Voight 1966; Mandl 1988). The geometrical properties of faults and their movements are thought to be controlled by the nature of the active stresses.

Keywords. Paleostress; relative stress magnitudes; Hun Graben; Jifarah Basin; stress tensor; fault-slip data. 
Paleostress analysis is the name popularly given to the estimation of principal stress orientation and ratios from data consisting of the orientation of fault planes and their corresponding slip direction indicators. A key understanding of tectonic events in studied areas was the work of Wallace (1951) and Bott (1959), who assumed that slip on a plane, occurs in the direction of the maximum resolved shear stress. Changes of stress field can cause new fault formation or the reactivation of older structures and multiple striations on some fault surfaces indicate that reactivation has occurred. The mechanism of this process is complicated by many factors such as the variability of the stress field in geological time, the precision of measurements, the production of spurious solutions, etc. (Fry 1999; Yamaji 2000; Shan et al. 2004a).

The stress regime is defined by the nature of vertical stress axes:

- normal faulting occurs when $\sigma 1$, the maximum resolved stress, is vertical ( $\sigma 2$ is $\left.\mathrm{SH}_{\max }\right)$,

- strike-slip faulting forms when $\sigma 1$ is horizontal $\left(\sigma 1 \mathrm{SH}_{\max }\right)$ and the intermediate resolved stress, $\sigma 2$ is vertical, and
- thrust/reverse faulting occurs when $\sigma 1$ is horizontal $\left(\sigma 1 \mathrm{SH}_{\max }\right)$ and $\sigma 3$, the minimum resolved stress is vertical.

The stress regimes also vary as a function of the stress ratio $\Phi$ which describes the shape of the stress ellipsoid from which ratios of principal paleostress magnitudes can be calculated: radial extension ( $\sigma 1$ vertical, $0<\Phi<0.25)$, pure extension $(\sigma 1$ vertical, $0.25<\Phi<0.75$ ), transtension $(\sigma 1$ vertical, $0.75<\Phi<1$ or $\sigma 2$ vertical, $1>\Phi>0.75)$, pure strike-slip ( $\sigma 2$ vertical, $0.75>\Phi>0.25)$, transpression ( $\sigma 2$ vertical, $0.25>\Phi>0$ or $\sigma 3$ vertical, $0>\Phi>0.25)$, pure compression ( $\sigma 3$ vertical, $0.25<\Phi<0.75)$ and radial compression $(\sigma 3$ vertical, $0.75<\Phi<1$ ) (Delvaux et al. 1997).

The orientation of the principal stresses and the stress difference ratio $(\Phi)$ are determined by selecting those measurements of small faults with obvious sense of movement given by slicken sides and mineral steps (as shown in figure 1).

In this study, paleostress orientations and principal stress ratios have been calculated using standard inversion methods in MyFault ${ }^{\mathrm{TM}}$ (v. 1.03) stereonet software, produced by Pangaea Scientific

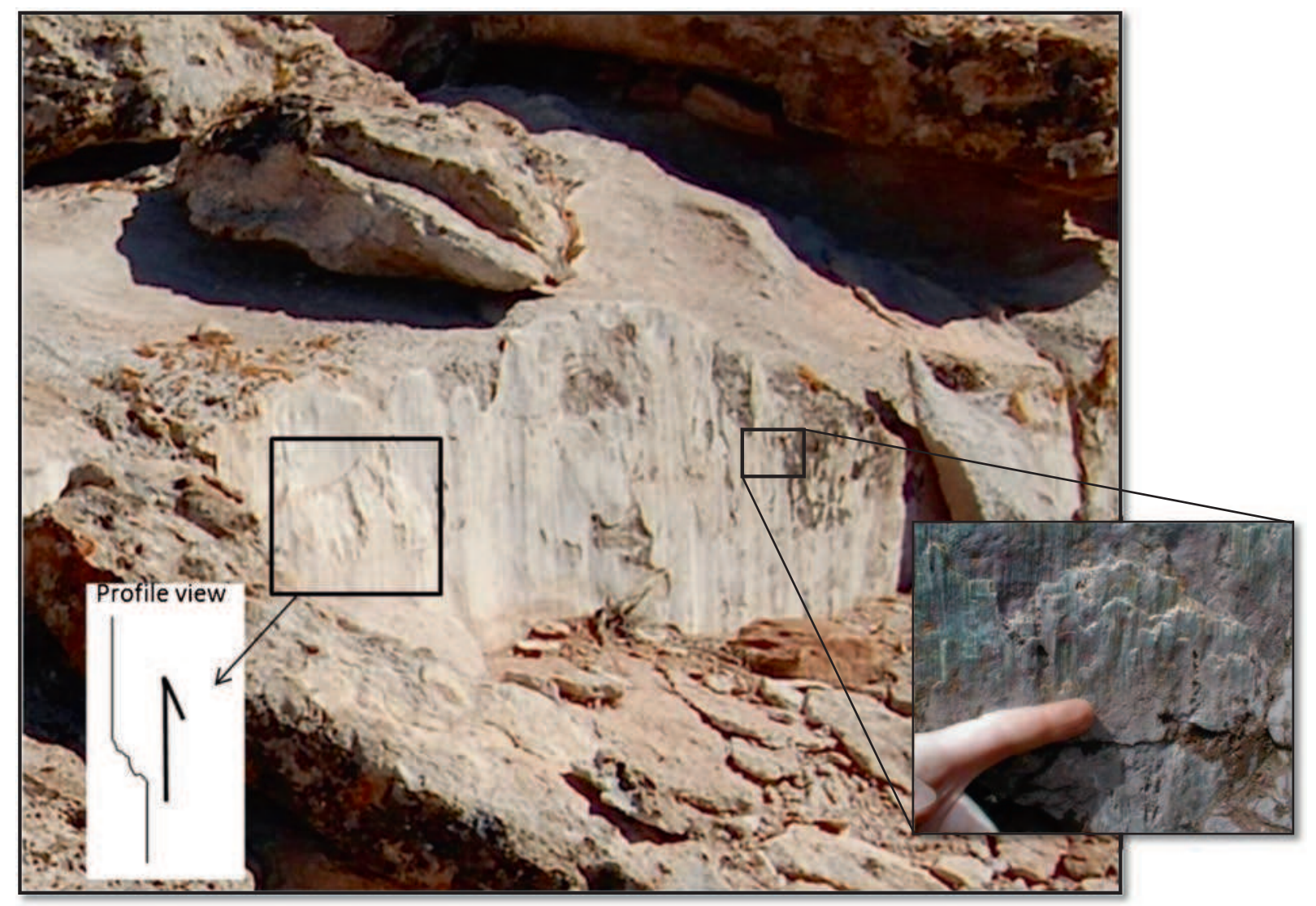

Figure 1. Example of a striated fault plane. Step-in fault plane is a kinematic indicator as illustrated in the inset diagram. 
Ltd. In all locations, faults of various scale (from centimetres to metres) cross the geologic formations, but only striated planes that indicate the direction of movement were measured. The sense of movement was identified using the steps on slicken lines and slicken fibres and other associated structures.

For each fault measured in the field, the following features were noted:

- the attitude of the plane;

- the stratigraphic units that were displaced;

- whenever possible, the relative order of movement;

- type of lineation;

- type of shear sense indicator. Each observation was given a confidence value of 1-4 (excellent to poor, as explained in Hardcastle 1989).

If no movement sense could be deduced, then the fault was not used in the analysis.

The purpose of paleostress analysis carried out in this study was to delineate the Cenozoic kinematic evolution of the study areas as a test of the prevailing tectonic models such as those of Anketell and Ghellali (1991) and Anketell (1996) models.

This study was part of a $\mathrm{PhD}$ thesis (Abdunaser 2012) and was carried out as a preliminary study ahead of planned fieldwork in the region.
Unfortunately, due to insecurity and instability in Libya during the year 2011-2012, this fieldwork is yet to happen. The data used in this study were collected by Abadi (2002) in the Hun Graben of the western Sirt Basin (figures 2 and 3) and Gamberlu (2007) for the region of Jifarah Basin and Jabal Nafusah Uplift of northwestern Libya (figures 2 and 4).

\section{Regional geology (structural, tectonic and stratigraphic background)}

Anketell (1996) suggested a general model (figure 5) to relate the tectonics of the Sabratah and Sirt basins with that of Cyrenaica. He recognized the south Atlas-Jifarah fracture zone as a dextral shear zone which marks the southern margin of the Pelagian Platform. To the east, in the Sirt Basin, the fracture zone feathers into a series of northwest-southeast splays which formed a block-faulted geometry characterized by numerous grabens and intervening horsts which can be regarded as a pull-apart structural regime (Goudarzi and Smith 1978; van Houten 1983; Anketell 1996). In the Anketell (1996) model, the main deformational event is related to a WNW-ESE extensional stress field (shown in figure 5 as a heavy dashed line with two

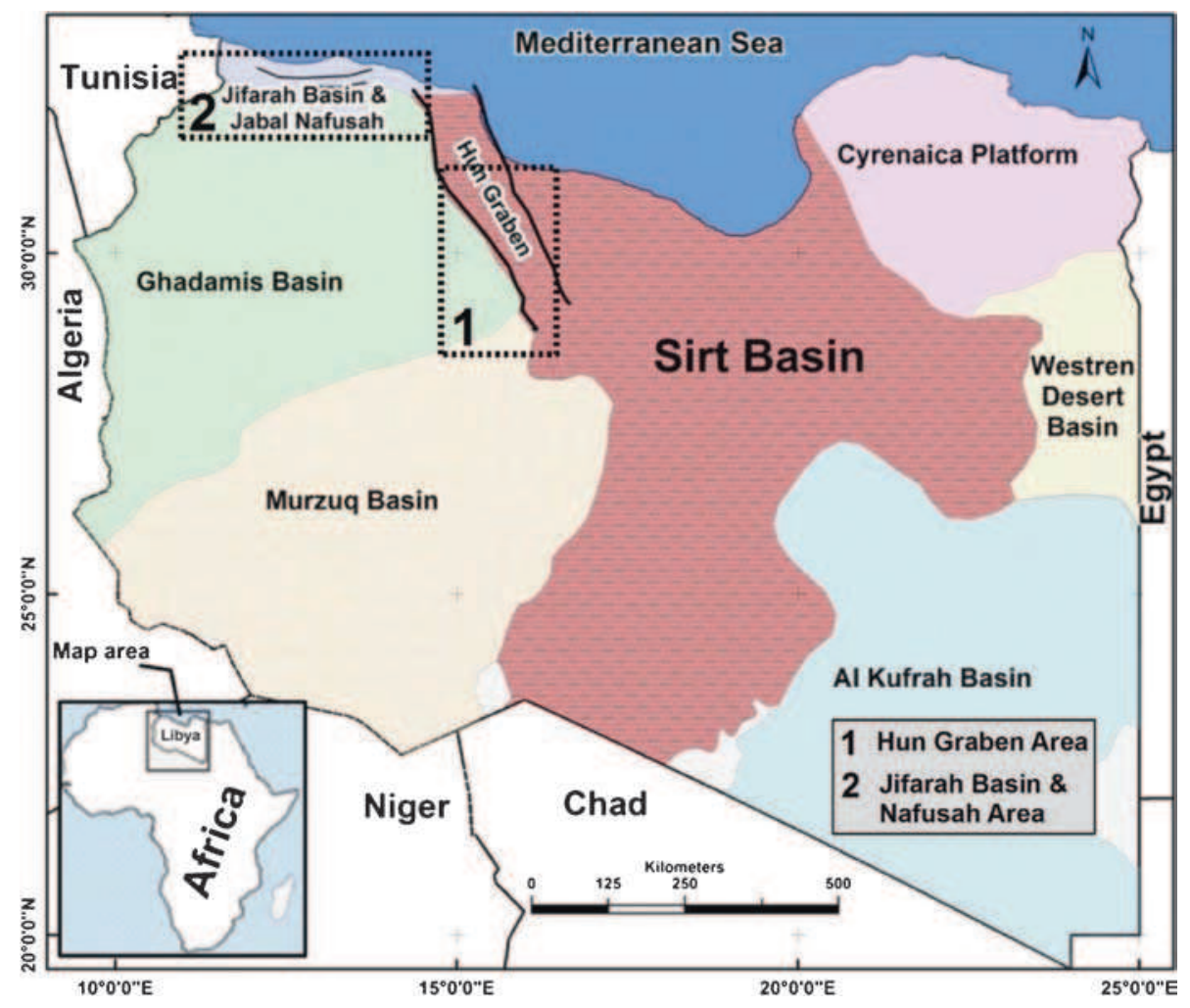

Figure 2. Location map of the study area. Dashed squares represent the study areas; 1: Hun Graben and 2: Jifarah Basin and Jabal Nafusah Uplift. 


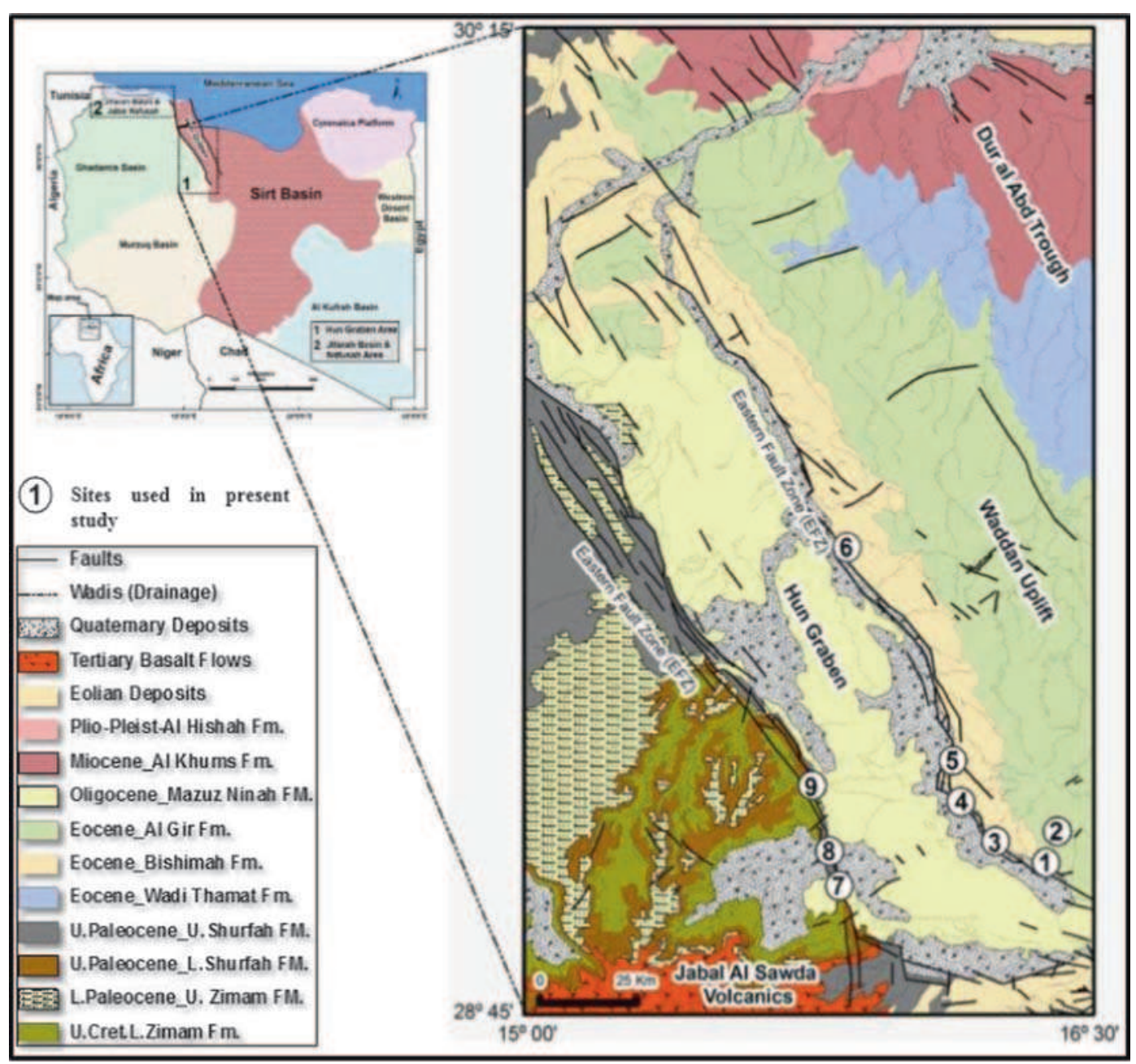

Figure 3. Geological map of Hun Graben (after Abdshakor and Shagroni 1984).

open-headed arrows) which we suggest was NESW-trending during Paleogene-Lower Miocene (Abdunaser and McCaffrey 2014). Slight changes in the stress field orientation towards ENE-WSW and $\mathrm{E}-\mathrm{W}$ directions, from the Sirt Basin towards the Abu Tumayam trough, during Paleogene time were possibly a consequence of the preexisting basement structures (Peregi et al. 2003; Fodor et al. 2005; Marović 2007).

After the Burdigalian, the western part of the Sirt Basin area was deformed in a stress field of NW-SE compression and perpendicular tension (Schäfer et al. 1980; Abdunaser and McCaffrey 2014). The western Sirt Basin terrains were subjected to inversion, uplifting and the accompanying erosion since that time. Older deposits (Eocene and Oligocene) occur in the north, while younger sediments (Lower Miocene) are preserved in the south, which indicates a southward tilting of the whole area. The basin inversion occurred along reactivated older faults of the Tibesti-Tripoli Arch (Cvetković et al. 2010). These lineaments were most likely the structures that controlled extrusions of basaltic magma along fissures indicated by the presence of basaltic dykes.

\subsection{Hun Graben}

The nature and origin of the Hun Graben is controversial. Klitzsch (1970) suggested that the tectonic development of the Hun Graben started prior to the Cretaceous and the western boundary of the graben is Paleocene in age. However, Cepek (1979) inferred that the graben is probably Oligocene in age, whilst Abadi (2002) considers the subsidence of the Hun Graben occurred during the Upper Cretaceous and reached its climax during the Paleocene-Early Eocene.

The western part of Hun Graben is a flat terrain that is slightly undulating but gently dipping to the northeast. The sedimentary rocks in this zone are from the Paleocene to recent epochs (figure 3) except in the southern part, where basalt flows from Jabal Assawda can be found. The eastern part of the Hun Graben is a hilly terrain terminating at the western margin in a steep scarp, 


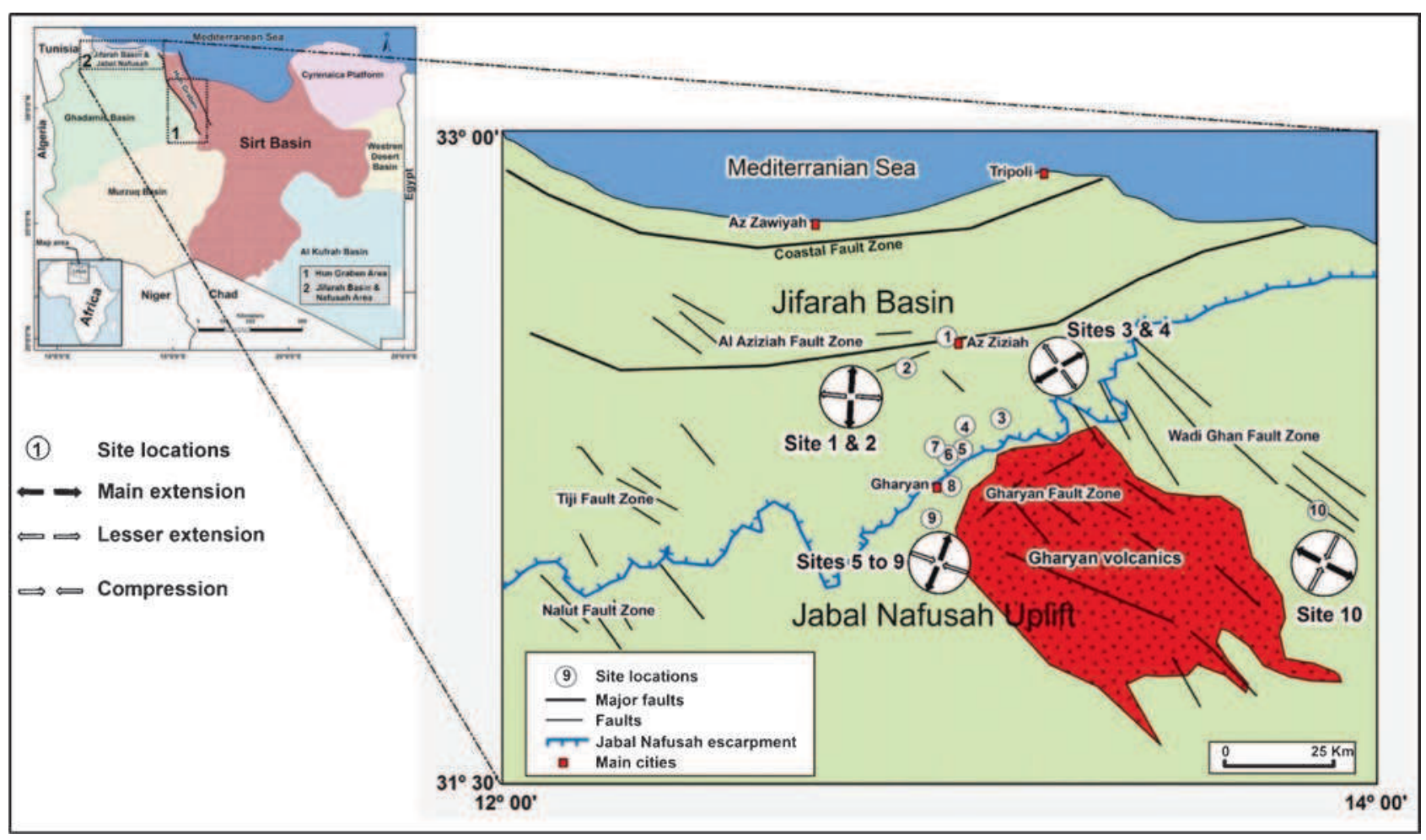

Figure 4. Generalized tectonic map for the region of Jifarah Basin and Jabal Nafusah Uplift of northwestern Libya showing major structural features and location of the sites used in this study.

while a regional NE-NNE dip is observed. To the east undulations and gentle dome like structures characterize the Sirt Basin area. Adjacent to the Hun Graben area, the faults trend NNW-SSE to NW-SE (figures 3 and 6). The differing fault trends suggest that the graben-forming forces have produced contrasting fault geometries at the boundaries that reflect the regional structure of the $\mathrm{Al}$ Qargaf Arch in the southern part (Abdshakoor and Shagroni 1984).

\subsection{Jifarah Basin and Nafusah Uplift, northwest Libya}

The Jifarah Basin in northwestern Libya (figure 4) is bounded by the Nafusah Uplift to the south and the offshore Sabratah Basin to the north. The basin is located at the eastern end of the South Atlas lineament or Saharan flexure which defines the southern margin of the Atlas fold belt (Dewey and Burke 1973). Anketell and Ghellali (1991) reported that the trend of basement fractures in the Jifarah region is controlled by the Hercyniam 'Jeffara flexure' and described four east-west trending fault zones (coastal, Alziziyah, Tiji and Nalut) (figure 4).

Generally, the region is comprised of gently dipping Mesozoic limestone with shale and sandstone overlain unconformably by Cenozoic deposits (Anketell and Ghellali 1991). The Jifarah fault is part of the Sabratah-Cyrenaica wrench zone in the
Anketell (1996) model (figure 5). This structure marks the boundary between the relatively stable shelf to the south and the unstable continental margin to the north. The Mesozoic basin-fill of the Jifarah Basin was affected by syn-depositional faulting during the Triassic and by shearing during the Neocomian, which reflected major tectonic activity along the southern margin of Tethys.

Anketell and Ghellali (1991) demonstrated that the dominant fault directions in the Mesozoic section are east-west and NNW-ESE with an enechelon arrangement which they interpreted as riedel shears and imbricate fan splays formed as a result of strike-slip movement on the south AtlasJifarah dislocation. They developed a model that suggested an analogy between the imbricate fan splays visible in the Wadi Ghan area, south of Al Aziziyah with strikingly similar fault trends in the Sirt Basin, and attributed both to strikeslip faulting associated with underlying basement dislocations.

The Nafusah Uplift is a major east-west ridge which separates the Ghadamis Basin from the Jifarah Basin (figure 4). It extends for $400 \mathrm{~km}$ from Misratah to the Tunisian border, and continues in Tunisia as the Dahar Uplift and in Algeria as the Talemzane Arch. It is bounded to the north by the Jifarah Fault and Jifarah Basin and to the south by the Ghadamis Basin. The southern margin is also partially faulted. During the Early Palaeozoic, 


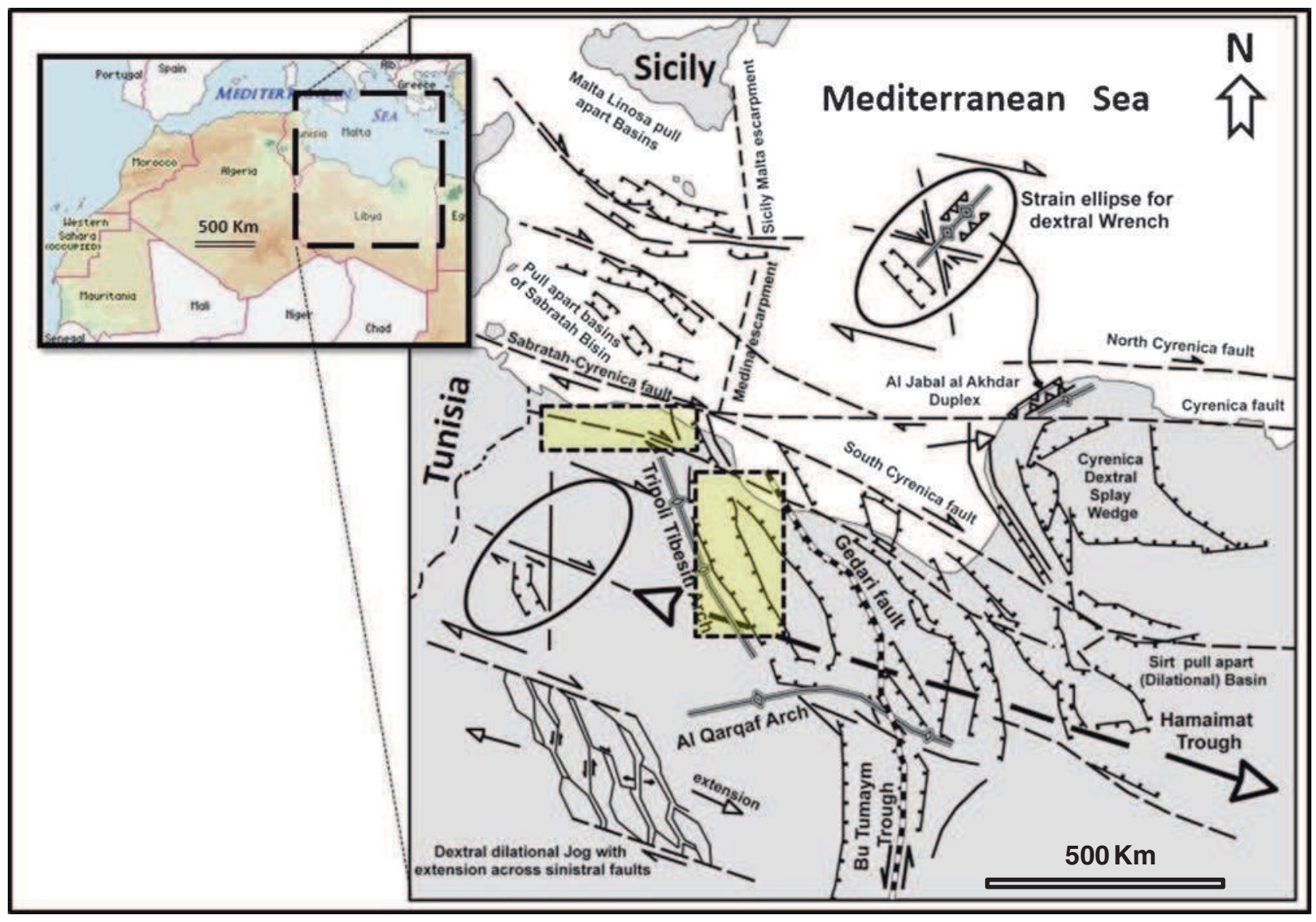

Figure 5. Interpretation of Sirt Basin relative to the Sabratah Basin and Cyrenaican Platform. Dashed squares represent the study areas (modified after Anketell 1996).

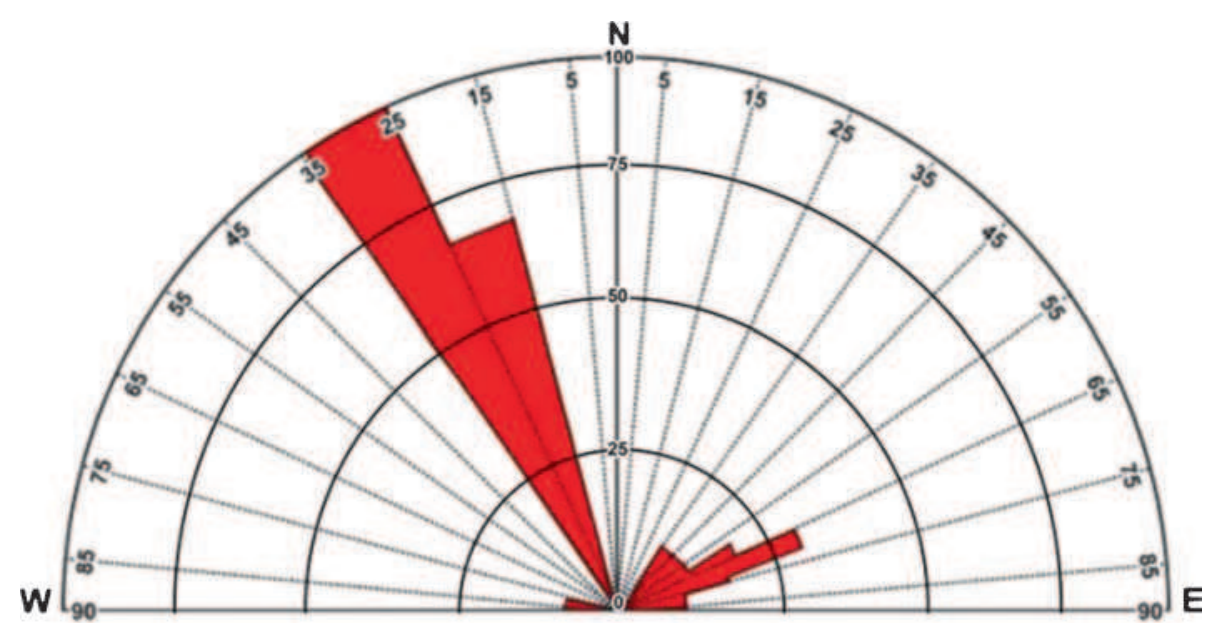

Figure 6. Rose diagram of Hun Graben faults.

the area of the Nafusah Uplift formed part of the Ghadamis Basin and a thick sequence of Palaeozoic rocks was deposited.

Sedimentation continued until the Paleocene, but the basin was caught up in the Eocene tectonism which reactivated the Nafusah Uplift and introduced a new generation of faulting in the
Jifarah Basin (El-Hinnawy and Cheshitev 1975). Eocene tectonism also led to the production of basaltic sills and flows near Gharyan, and the volcanic activity has continued until recent times. A major escarpment formed along the line of the Jifarah Fault and Jurassic and Triassic rocks outcrop both on the escarpment and on the Jifarah 
Basin. Extensive pre-Miocene erosion removed much of the Mesozoic sediments from the basin, and pre-Miocene subcrop shows a complex pattern.

The tectonic frame of the African Plate in the Mediterranean can be appreciated within the context of the Meso-Cenozoic convergence between Africa and Eurasia and the subsequent formation of collisional belts along their margins (Dercourt et al. 1986). The north African Plate has subducted below the Eurasian continent along the Maghrebian-Apennine front in the west and below the Hellenic front in the east (Faccenna et al. 2003). Although the studied areas in this work are considered to be far from Mediterranean convergent margin, the high-magnitude seismicity historically recorded, suggests that this area is currently deforming (Capitanio et al. 2012). How this deformation relates to surrounding tectonics of the Africa-Europe convergence is still poorly known. Here, we use the paleostress analysis carried out in this study to show the recent deformation history that affected Jifarah Basin and Nafusah Uplift and also reactivated the western bordering structures of Sirt Basin.

\section{Hun Graben results}

Data from nine sites were made available for the Hun Graben area (Abadi 2002) from the east and west margins and 150 fault slip data were used for the calculations. Measurements were made at six different locations over about $50 \mathrm{~km}$ along the east fault zone of the Hun Graben (EFZ). Two data sites (sites 1 and 2) were located in NE oriented road cuts perpendicular to the EFZ scarp. These outcrops are made of dolomitic limestone of the Paleocene Shurfah Formation and of chalky limestone and dolomitic limestone of the Eocene Bishimah Formation (Abdshakoor and Shagroni 1984). The other four sites are located along the main EFZ (figure 3). Site 3 of these locations (figure 3 ) is located in a N-S trending fault zone (high-angle normal faults), with the downthrown block always to the west.

The west fault zone (WFZ) was sampled at three sites (7-9) all on the main fault in outcrops of the Paleocene Shurfah and Zimam Formations (figure 3). The measured fault slips were obtained from outcrops comprised of Paleocene and Eocene sedimentary sequences (Abdshakoor and Shagroni 1984) which means the measured fault slips belong to these ages or later.

\subsection{Inversion procedures}

In total, 150 faults with good kinematic indicators were recorded (figure 3), which can be used for kinematic inversion. Two separate steps for sorting the fault data into populations for inversion analysis have been applied during the present study. The first step simply uses the entire unsorted dataset (i.e., all 150 faults and fault striae), while the second (step 2), required manual sorting and separate analysis of the data into fault systems.

In step 1, after the input of raw data, data files were corrected to ensure that all striae lie perfectly on their respective fault planes (i.e., no angular mismatch). To do this, fault strikes were rotated along the common plane and because the collected data were measured using dip directions the data strikes were changed to a range from 0 to $360^{\circ}$ to compute the stress tensor using the MyFault software. Those faults with high misfit angles $\left(>40^{\circ}\right)$ relative to the inversion result were rejected and the inversion rerun. This procedure was repeated and the stress tensor was recomputed again only for 124 faults.

In step 2, datasets were formed according to the geographic position of the study sites. The Hun Graben depression acted as a dividing line between the eastern (EFZ) and western (WFZ) groups of datasets. The aim of this step was to get enough data to compute paleostress tensors independently between the EFZ and WFZ of the Hun Graben fault system. Splitting the data up by area may be geologically more meaningful than analysing the data by the age of the rocks in which the faults are found as Abadi (2002) had done. The justification for this different approach is that strike-slip and dip-slip normal faults may be of the same age, if the area has experienced transtensional deformation (De Paola et al. 2006).

In the bulk inversion of all (whole Hun Graben) the fault data (step 1), three separate sets of paleostress axes were derived, and one for each fault system was analyzed. The resultant paleostress tensor for the whole area was grouped according to the orientation of the principal stress axes, i.e., system 1 left normal dip-slip, system 2 normal dip-slip and system 3 left normal strike-slip faults (figure 7 and table 1). On the basis of the orientation relation of the structure and tensors, it appears to be possible to correlate a specific paleostress tensor with a specific rift structure. The parameters of the reduced tensor for the investigated area are illustrated in table 1 showing the principal stress and the value of $\Phi$, which expresses a linear relation between the principal stress directions.

The directions of extension computed from fault slip datasets are remarkably homogeneous in all sites (figure $7 \mathrm{a}-\mathrm{f}$ ). These major faults control the geometry of the Hun Graben and reflect the regional NNE-SSW extension that has rotated anti-clockwise towards NNW-SSE directions, superimposed with transtension, which were 


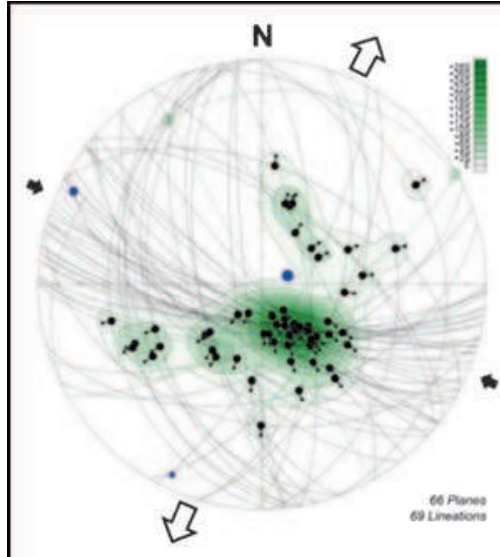

(a) System 1: Left normal dip-slip

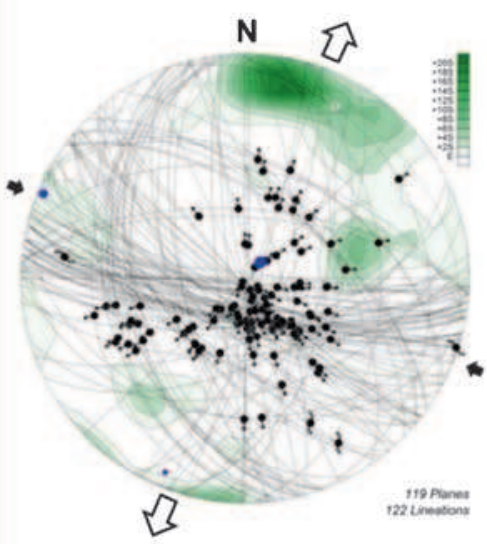

(d) Left normal strike-slip faults

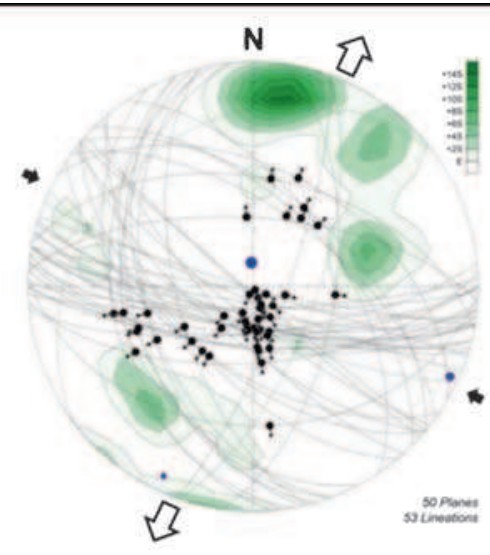

(b) System 2: Normal dip-slip

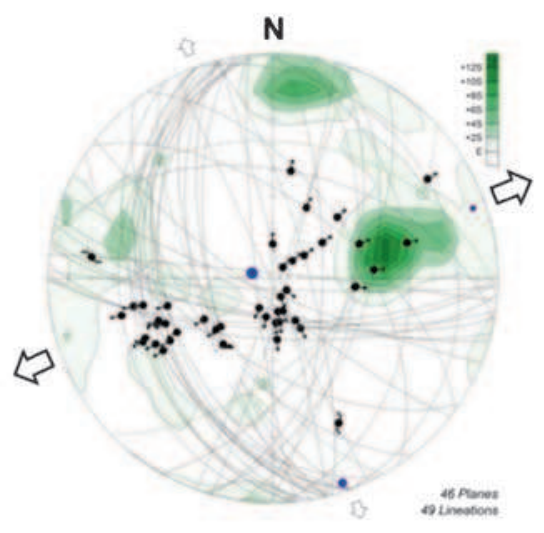

(e) The eastern fault zone (EFZ) of Hun Graben without area $1 \& 2$

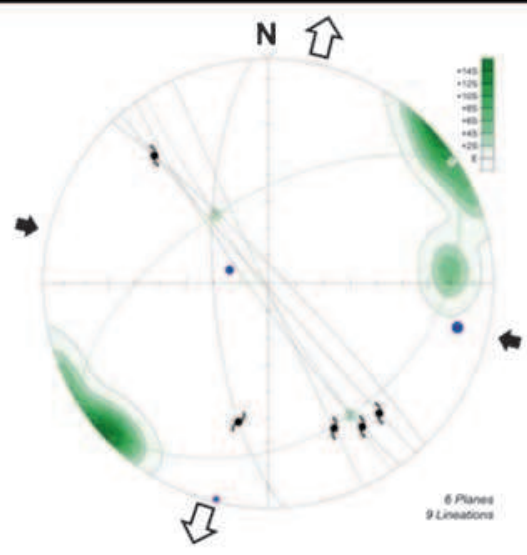

(c) System 3: Left normal strike-slip faults

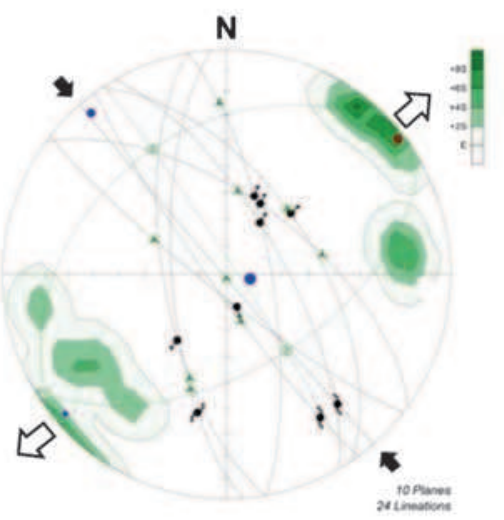

(f) The west fault zone (WFZ) of Hun Graben

Figure 7. Results of different stress phases for the Hun Graben. Field data diagram are Schmidt's projections of lower hemisphere. Faults are great circles, slickenside lineations are dots with arrows indicating the sense of motion of the hanging wall. Computed stress axes are represented as large blue dot $(\sigma 1)$, medium blue dot $(\sigma 2)$ and small blue dot $(\sigma 3)$. Large divergent white arrows indicate the horizontal extensional stress direction $(\sigma 3)$, whilst large convergent black arrows indicate maximum principal stress axis $(\sigma 1)$.

a consequence of the pre-existing basement structures (Peregi et al. 2003; Fodor et al. 2005; Marović 2007) described in many studies (Schäfer et al. 1980; Abadi 2002).

The interpretation of Hun Graben data implies that the dominant directions of extension, average $\mathrm{N} 20-25^{\circ} \mathrm{E}$ in the Hun Graben with minor predicted directions of extension, averaging $\mathrm{N} 10-15^{\circ} \mathrm{W}$ at the eastern margin (EFZ), show that the $\sigma 3$ directions have rotated counter-clockwise from NNE-SSW to NNW-SSE. It seems that two principal extensions have affected the graben, one which is perpendicular (transverse) to the basin axis to give normal faults, whilst the second is oblique to the axis and responsible for the left normal and strike slip faults that mainly appear along the western margin of the Hun Graben.

On other hand, rift systems that undergo extension oblique to the basin bounding faults commonly show complex multimodal fault patterns (e.g., Withjack and Jamison 1986; Clifton et al. 2000; Dewey 2002; De Paola et al. 2005a, b). As the extension directions calculated in Hun Graben appear slightly oblique to the trend of the Hun Graben bounding faults, it is likely that this area has undergone transtensional deformation.

Regional extension related to the subsidence of the NW-SE elongated Sirt Basin structures that were active during the late Cretaceous extends north westward to the offshore basins. The late Cretaceous extensions evidenced in north central Libya is characterized by a mainly NE-SW to E-W component. This late Cretaceous normal faulting affected the whole north African margin, forming NW-SE to NNW-SSE striking basins. Such a NESW extension was active eastward in the Sirt Basin (Baird et al. 1996), and offshore in the Tarabulus Basin and in the Pelagian shelf (Anketell 1996).

The WNW-ESE compression and NNE-SSW extension suggested by this study is consistent 
Table 1. Results of the reduced paleostress tensors from fault-slip data of the Hun Graben.

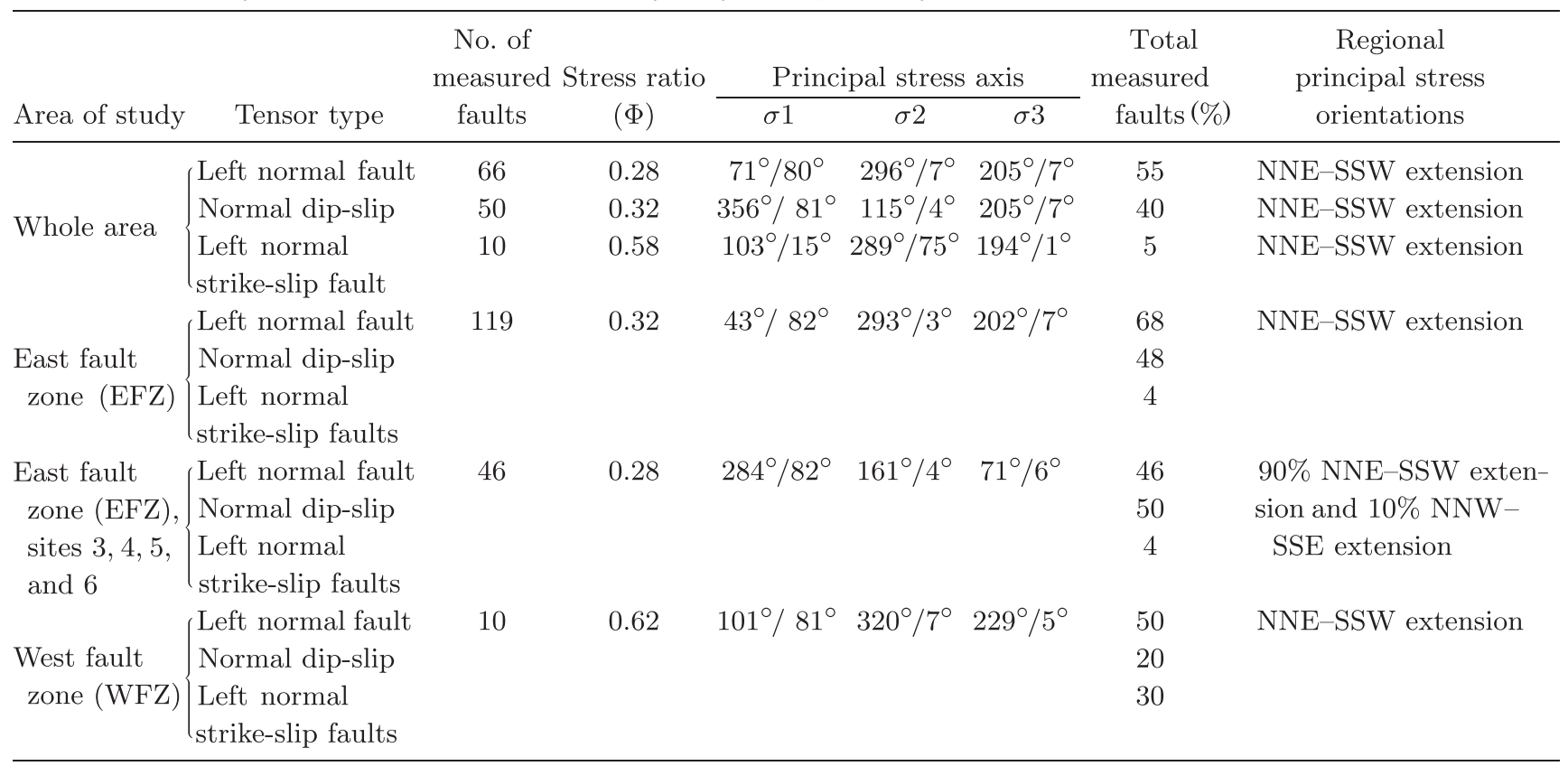

with progressive collisional coupling of Africa and Europe, under approximately northwest-southeast compressional stresses during the Late Eocene (Ziegler et al. 1998; Cloetingh et al. 2005). During this time, in the Sirt Basin, a thick succession of postrift sediments were being deposited from the Late Eocene until the Miocene, whilst in the western part of the basin, large parts of the Tertiary sequence were being eroded (e.g., Gumati and Schamel 1988), which is contemporaneous with the widespread volcanic activity. In addition, volcanic activity occurred immediately west of the Sirt Basin (Al Haruj volcanics), mainly as an outcome of the intersection of differently-oriented fracture zones (Al Qargaf and Tripoli-Tibesti arches) but possibly also affected by the intersection of NNE-SSW and NNW-SSE extension which is the outcome in this work. This volcanic episode was widespread in east and northwest Africa (Abadi et al. 2008) and has a range of age dates, suggesting Early Eocene to Pliocene (Wilson and Guiraud 1992).

Dextral strike-slip movement along the main Europe-Africa plate margins along the SabratahCyrenaica fault system may have caused the renewed rifting and further extension of the Sirt Basin and east-west-oriented basins in Egypt (Anketell 1996; Guiraud et al. 2001) and would be compatible with north-northeast-south-southwest extensional stresses.

The rejuvenation of strike-slip faults displacements, under fluctuating stress fields, facilitated the vertical migration of hydrocarbons (Guiraud and Bosworth 1997). This interpretation is in agreement with Eocene-present-day paleostress analysis in the Hun Graben although the strikeslip faults and paleostress changes are certainly present but play a minor role which represents only $5 \%$ of the total measured faults as shown in this study.

The western edge of the Sirt Basin, including the Hun Graben, has been one of the most seismically active regions in Libya throughout historic time (Suleiman and Doser 1995). This was manifested as a complex series of strike-slip earthquakes along the eastern boundary fault of the graben in 1935.

\section{Northwest Libya (Jifarah Basin and Jabal Nafusah Uplift)}

The aim of this part of the study was to examine the Mesozoic fault kinematics in another basement province outside the Sirt Basin. Provided the faults are of similar age, any difference in basement influence compared to the Sirt Basin should be reflected in different fault geometries and kinematics. Anketell and Ghellali (1991) demonstrated that this area is dominated by east-west and NNWESE fault directions in the Mesozoic section with an en echelon arrangement, which they interpreted as Riedel shears and imbricate fan splays formed as a result of strike slip movement on the south Atlas-Jifarah dislocation. They developed a model which suggested an analogy between the imbricate fan splays visible in the Wadi Ghan area, south of Al Aziziyah with the strikingly similar fault trends in the Sirt Basin, and attributed both to strike-slip faulting associated with underlying basement dislocations. 


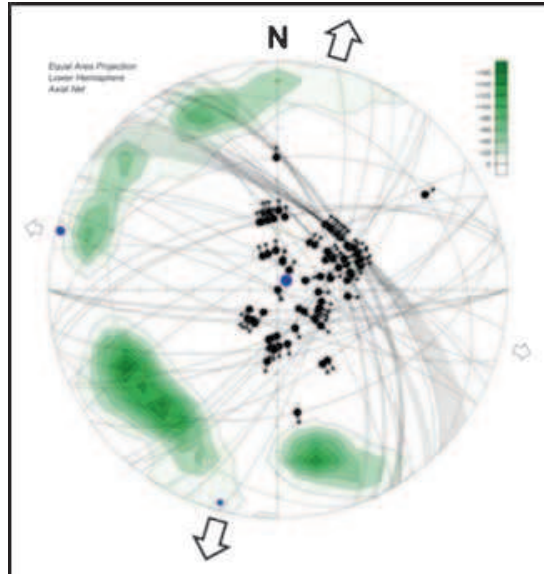

(a) System 1: Normal dip-slip.

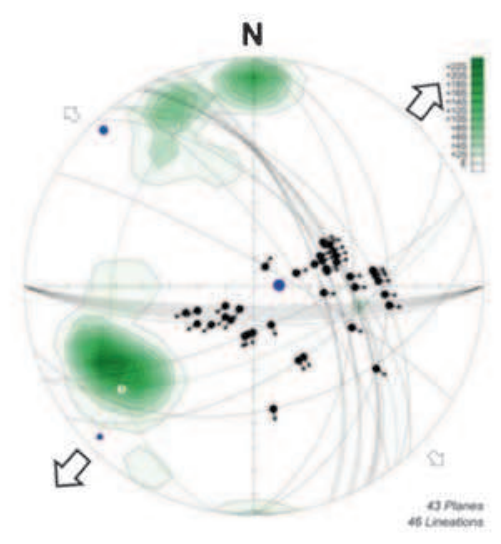

(d) Areas $3 \& 4$

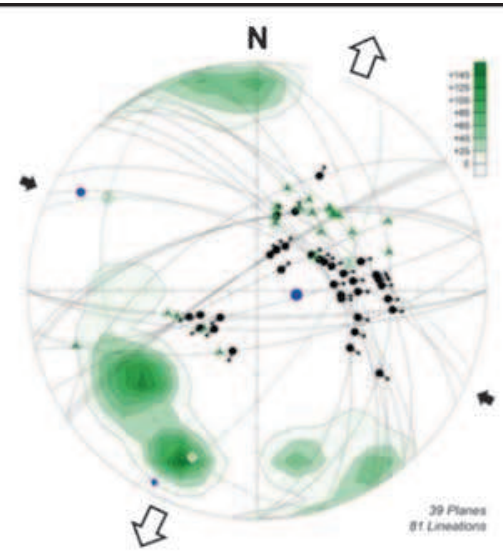

(b) System 2: Right normal dip-slip

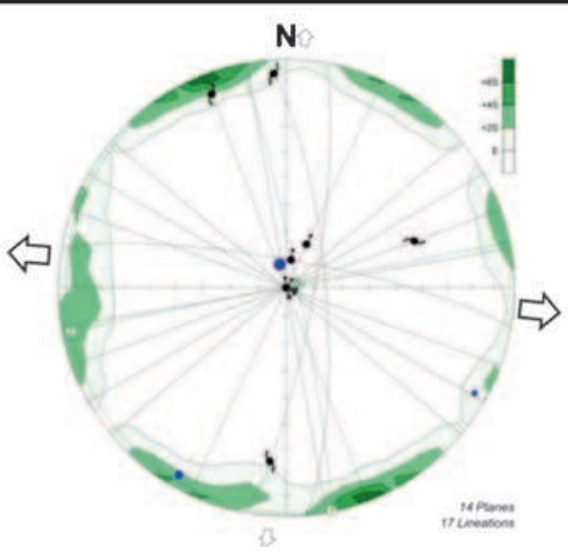

(c) Areas $1 \& 2$

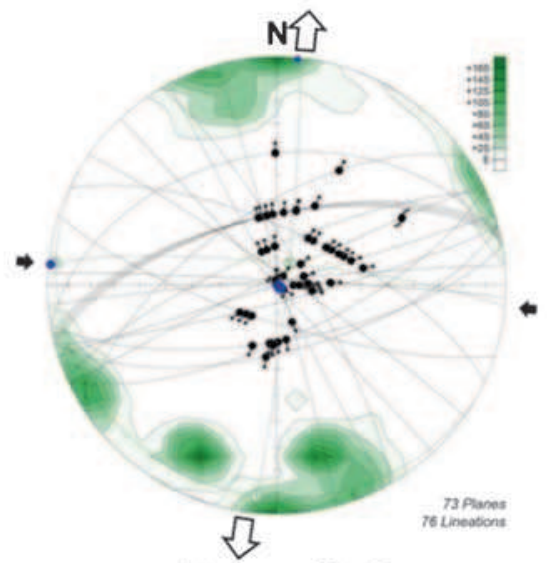

(e) Areas 5 to 9

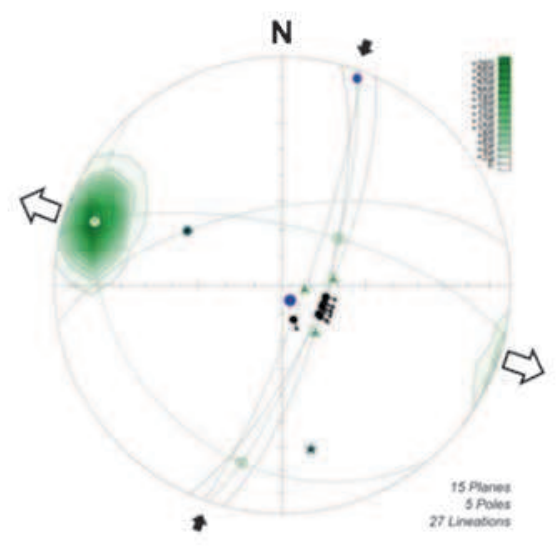

(f) Area 10

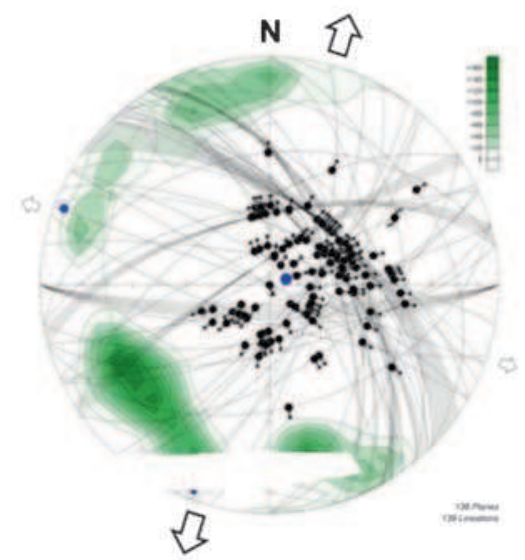

(g) All NW Libya data after misfit

Figure 8. Results of different stress phases for northwest Libya (Jifarah Basin and Nafusah Uplift). Field data diagrams are Schmidt's projections of lower hemisphere. Faults are great circles, slickenside lineations are dots with arrows indicating the sense of motion of the hanging wall. Computed stress axes are represented as large blue dot $(\sigma 1)$, medium blue dot $(\sigma 2)$ and small blue dot $(\sigma 3)$. Large divergent white arrows indicate the horizontal extensional stress direction $(\sigma 3)$, whilst large convergent black arrows indicate maximum principal stress axis $(\sigma 1)$.

Data from 10 sites were made available to the present study from northwest Libya (Jifarah Basin and Nafusah Uplift) and 200 fault slip data were used in the calculation (figure 4). Sites 1 and
2 were measured in the Jifarah Basin along the Al Azizyah fault zone (AZFZ), whilst sites 3 and 4 were located on the Jabal Nafusah escarpment fault zone (JEFZ). The sites 5-9 measurements 
Table 2. Results of the reduced paleostress tensors from fault-slip data of northwest Libya (Jifarah Basin and Nafusah Uplift).

\begin{tabular}{|c|c|c|c|c|c|c|c|}
\hline \multirow[b]{2}{*}{ Area of study } & \multirow[b]{2}{*}{ Tensor type } & \multirow{2}{*}{\multicolumn{2}{|c|}{$\begin{array}{l}\text { No. of Stress } \\
\text { measured ratio } \\
\text { faults }(\Phi)\end{array}$}} & \multicolumn{2}{|c|}{ Principal stress axis } & \multirow{2}{*}{$\begin{array}{l}\% \text { total } \\
\text { measured } \\
\text { faults }\end{array}$} & \multirow[b]{2}{*}{ Regional principal stress orientations } \\
\hline & & & & $\sigma 1$ & $\begin{array}{ll}\sigma 2 & \sigma 3\end{array}$ & & \\
\hline & Right normal fault & 39 & 0.28 & $96^{\circ} / 76^{\circ}$ & $299^{\circ} / 13^{\circ} 208^{\circ} / 5^{\circ}$ & 29 & $\begin{array}{l}\text { Predominantly NNE-SSW }\left(\mathrm{N} 25^{\circ} \mathrm{E}\right) \text { extension } \\
\text { and less WNW-ESE }\left(\mathrm{N} 115^{\circ} \mathrm{E}\right) \text { compression }\end{array}$ \\
\hline Whole area & Normal dip-slip & 96 & 0.14 & $42^{\circ} / 86^{\circ}$ & $285^{\circ} / 2^{\circ} 195^{\circ} / 4^{\circ}$ & 71 & $\begin{array}{l}\text { Predominantly NNE-SSW }\left(\mathrm{N} 12^{\circ} \mathrm{E}\right) \text { and less } \\
\text { WNW-ESE }\left(\mathrm{N} 102^{\circ} \mathrm{E}\right) \text { extensions }\end{array}$ \\
\hline $\begin{array}{l}\text { Al Azizyah fault zone } \\
\text { (AZFZ), sites } 1 \text { and } 2\end{array}$ & $\begin{array}{l}\text { Right normal fault } \\
\text { Normal dip-slip } \\
\text { Left strike slip fault }\end{array}$ & 13 & 0.02 & $345^{\circ} / 81^{\circ}$ & $210^{\circ} / 6^{\circ} 119^{\circ} / 6^{\circ}$ & $\left\{\begin{array}{c}8 \\
69 \\
23\end{array}\right.$ & $\begin{array}{l}\text { Predominantly } \mathrm{N}-\mathrm{S} \text { to } \mathrm{NNE}-\mathrm{SSW}\left(\mathrm{N} 2^{\circ} \mathrm{E}\right) \text { and } \\
\text { less } \mathrm{E}-\mathrm{W} \text { to } \mathrm{WNW}-\mathrm{ESE}\left(\mathrm{N} 92^{\circ} \mathrm{E}\right) \text { extensions }\end{array}$ \\
\hline $\begin{array}{l}\text { Jabal Nafusah escarpment } \\
\text { fault zone (JEFZ), } \\
\text { sites } 3 \text { and } 4\end{array}$ & $\begin{array}{l}\text { Right normal fault } \\
\text { Normal dip-slip }\end{array}$ & 43 & 0.25 & $88^{\circ} / 81^{\circ}$ & $316^{\circ} / 6^{\circ} 226^{\circ} / 7^{\circ}$ & $\left\{\begin{array}{l}33 \\
67\end{array}\right.$ & $\begin{array}{l}\text { Predominantly } \mathrm{NE}-\mathrm{SW}\left(\mathrm{N} 42^{\circ} \mathrm{E}\right) \text { and } \\
\text { less } \mathrm{NW}-\mathrm{SE}\left(\mathrm{N} 132^{\circ} \mathrm{E}\right) \text { extensions }\end{array}$ \\
\hline $\begin{array}{l}\text { Gharyan fault zone (GFZ), } \\
\text { sites } 5-9\end{array}$ & $\begin{array}{l}\text { Right normal fault } \\
\text { Normal dip-slip }\end{array}$ & 73 & 0.32 & $123^{\circ} / 89^{\circ}$ & $275^{\circ} / 1^{\circ} \quad 5^{\circ} / 1^{\circ}$ & $\left\{\begin{array}{l}26 \\
74\end{array}\right.$ & $\begin{array}{l}\text { Predominantly } \mathrm{N}-\mathrm{S} \text { to NNE-SSW }\left(\mathrm{N} 5^{\circ} \mathrm{E}\right) \\
\text { extension and less E-W to WNW-ESE } \\
\left(\mathrm{N} 95^{\circ} \mathrm{E}\right) \text { compression }\end{array}$ \\
\hline $\begin{array}{l}\text { Wadi Ghan fault zone } \\
\qquad(\text { WFZ), site } 10\end{array}$ & $\left\{\begin{array}{c}\text { Normal fault } \\
\text { Compression } \\
\text { fracture }\end{array}\right.$ & \} 15 & 0.32 & $43^{\circ} / 82^{\circ}$ & $293^{\circ} / 3^{\circ} 202^{\circ} / 7^{\circ}$ & $\left\{\begin{array}{l}67 \\
33\end{array}\right.$ & $\begin{array}{l}\text { Predominantly WNW-ESE }\left(\mathrm{N} 109^{\circ} \mathrm{E}\right) \\
\text { extension and less NNE-SSW } \\
\left(\mathrm{N} 19^{\circ} \mathrm{E}\right) \text { compression }\end{array}$ \\
\hline
\end{tabular}


were taken from Jabal Nafusah Uplift along the Gharyan fault Zone (GFZ), whilst site 10 is located on the eastern side of Jabal Nafusah Uplift along the Wadi Ghan fault zone (WGFZ).

\subsection{Inversion procedures}

The same procedures used in the Hun Graben analysis have been applied to data from this area using MyFault ${ }^{\mathrm{TM}}$ stereonet software and data sorting.

In bulk inversion of all the (Jifarah Basin and Nafusah Uplift) fault data (step 1), three separate sets of paleostress axes can be derived, one for each fault system analyzed. The resultant paleostress tensor for the whole area was grouped according to the orientation of the principal stress axes (i.e., system 1 right normal dip-slip, system 2 normal dip-slip and system 3 left normal strike-slip faults), which are very rare and neglected (figure $8 \mathrm{a}-\mathrm{b}$ and table 2). On the basis of orientation relationships between the structures and tensors, it appears possible to correlate a specific paleostress tensor with a specific rift structure. The parameters of the reduced tensor for the investigated area are illustrated in table 2, showing the principal stress and the number for $\Phi$, which expresses a linear relation between the principal stress directions.

It is clear from this study that the area of northwest Libya is predominantly characterized by NNE-SSW directions of extension ranging from $\mathrm{N} 12^{\circ} \mathrm{E}$ to $25^{\circ} \mathrm{E}$ with lesser expected ENE-WSW directions of extension averaging $\mathrm{N} 102^{\circ} \mathrm{E}$, where the $\sigma 3$ directions rotate clockwise from NNE-SSW to ENE-WSW. The area was also affected by minor ENE-WSW direction of compression which led to the development of right normal faults.

Paleostress results from this study has showed that the Gharyan region has experienced extension orientated in a NNE-SSW direction and ESEWNW compression which might have resulted from volcanic intrusion, doming and folding where the beds at Gharyan area are highly inclined due to the presence of the Gharyan dome, and they are arranged into hog-backed ridges around the dome centre (Gray 1971).

\subsubsection{Extension regimes}

The tectonic regime for the whole area is characterized by NNE-SSW extension with a lesser ESEWNW component (figure $8 \mathrm{~g}$ ) and represents the tensor inversion direction of:

- Pure extension N-S to NNE-SSW $\left(\mathrm{N} 2^{\circ} \mathrm{E}\right)$ and less E-W to WNW-ESE $\left(\mathrm{N} 92^{\circ} \mathrm{E}\right)$ extensions. NNE-SSW extension regime located mainly in the Jifarah Plain (figure 8 and table 2).
- $\mathrm{NE}-\mathrm{SW}\left(\mathrm{N} 42^{\circ} \mathrm{E}\right)$ and less NW-SE (N132 $\left.{ }^{\circ} \mathrm{E}\right)$ extensions of Jabal Nafusah escarpment fault zone (JEFZ).

- $\mathrm{N}-\mathrm{S}$ to NNE-SSW $\left(\mathrm{N} 5^{\circ} \mathrm{E}\right)$ extension of Jabal Nafusah Uplift along Gharyan fault zone (GFZ).

- WNW-ESE (N109 $\left.{ }^{\circ} \mathrm{E}\right)$ extension of Jabal Nafusah Uplift along Wadi Ghan fault zone (WFZ).

\subsubsection{Compressional regime}

This tectonic regime is restricted mainly on the Jabal Nafusah Uplift area as (figure 4) E-W to WNW-ESE $\left(\mathrm{N} 95^{\circ} \mathrm{E}\right)$ compression along Gharyan fault zone (GFZ), and NNE-SSW $\left(\mathrm{N} 19^{\circ} \mathrm{E}\right)$ compression along Wadi Ghan fault zone (WFZ).

This paleostress analysis results and the previous studies support the suggested original view that these E-W and NW-SE trending structural trends are inherited likely from Jurassic or Upper Cretaceous and were probably reactivated in Ecocene age (Anketell and Ghellali 1991).

\section{Discussion}

\subsection{Northwest Libya (Jifarah Basin and Nafusah Uplift) and Hun Graben relationship}

The northwest Libya structure trends represent the remnants of reactivated structures that formed under the stress regimes generated during the tectonic evolution of north Africa. Late PermianMiddle Triassic dextral (clockwise) motion of Africa relative to Eurasia created a westwardnarrowing wedge-shaped arm of the paleo-Tethys (Robertson and Dixon 1984) and Permian clastic deposition dominated the Jifarah Basin. The area became a stable platform from the Late Cretaceous to the Miocene following the main rifting during Late Triassic up to the end of the Early Jurassic. Downwarping in the Miocene resulted in the deposition of Miocene sediments (Tawadros 2001).

Capitanio et al. (2012) pointed out that the progressive closure of the Ionian basin and the pull of subducting Hellenic slab have conferred complex deformation along the Libyan margin during the Paleocene, with inversion in NW Libya (Tripolitania) and Cyrenaica bordering the subsiding domain of the Sirt Basin (van der Meer and Cloetingh 1993; Abadi et al. 2008; Bosworth et al. 2008; Capitanio et al. 2009).

Most of the faults observed in the Hun Graben and northwest Libya (Jifarah Basin and Nafusah Uplift) correspond to minor structures with displacement ranging from several centimetres to several metres. Various types of faults (normal faults, left normal faults, right normal faults and strikeslip faults) with their rake ranging from $51^{\circ}$ to $80^{\circ}$ 
and their dip ranging from $70^{\circ}$ to $90^{\circ}$ (high-angle normal faults) are present. Our analysis shows that a NNE-SSW directed extension regime with WNW-ESE compression is recorded by most of the measurements in the study area.

The directions of extension computed from the fault slip datasets are remarkably homogeneous in all sites. The WNW-ESE compression and NNE-SSW extension that result from this study (figure $9 \mathrm{a}, \mathrm{b}$ and $\mathrm{c}$ ) are consistent with progressive collisional coupling of Africa and Europe, under approximately WNW-ESE compressional stresses during Late Eocene-aged (Ziegler et al. 1998; Cloetingh et al. 2005) or alternatively due to a foreland bulge in front of the inversional deformation of the Cyrenaica Platform in combination with far-field Alpine effects.

In the Hun Graben (table 1), about $56 \%$ of the observed faults are predominantly left normal faults (oblique dip-slip component), whilst in northwest Libya (Jifarah Basin and Nafusah Uplift), right normal slip faults represent about $29 \%$ of the total measured faults with a rake ranging between $101^{\circ}$ and $130^{\circ}$ which indicates predominantly NNE-SSW $\left(\mathrm{N} 25^{\circ} \mathrm{E}\right)$ extension and less WNW-ESE $\left(\mathrm{N} 115^{\circ} \mathrm{E}\right)$ compression (table 2$)$.

However, $71 \%$ of the observed faults are predominantly normal faults where the compressional regime is restricted mainly on the Jabal Nafusah Uplift area (figure 4) as E-W to WNW-ESE $\left(\mathrm{N} 95^{\circ} \mathrm{E}\right)$ compression along Gharyan fault zone (GFZ), and NNE-SSW (N19 $\left.{ }^{\circ} \mathrm{E}\right)$ compression along Wadi Ghan fault zone (WFZ). The combination of dip-slip normal faulting resulted from a horizontal NNE-SSW trending $\sigma 3$ and vertical $\sigma 1$ stress axes, and the left normal and strike slip faults might correspond to an overall transtensional deformation regime in the formation of Hun Graben that extends to the whole Sirt Basin.

It is clear from this study that the two areas are predominantly characterized by NNE-SSW directions ranging from $\mathrm{N} 12^{\circ} \mathrm{E}$ to $25^{\circ} \mathrm{E}$ with a minor component of ENE-WSW extension with an average $\mathrm{N} 102^{\circ} \mathrm{E}$, where the $\sigma 3$ directions rotate clockwise from NNE-SSW to ENE-WSW in northwest Libya (Jifarah Basin and Nafusah Uplift). It also seems that the area was affected by minor ENE-WSW direction compression which led to the development of the right normal faults. However in the Hun Graben, minor expected directions of extension may average NNW-SSE, where the $\sigma 3$ directions rotate counter-clockwise from NNESSW to NNW-SSE. Anketell and Ghellali (1991), Anketell (1996) and Abadi (2002), Abadi et al. (2008) thought that the western Sirt Basin boundary along the Hun Graben was indicative of regional extension related to the subsidence of the NW-SE elongated Sirt Basin structures, active during Late Cretaceous and extended northwestward to the offshore basins in the Sabratah Basin and in the Pelagian shelf (figure 5) which means that these areas might be related to each other in their original formation.

The Hun Graben boundaries are formed by segmented faults (Abdunaser and Reeh 2007; Abdunaser and McCaffrey 2014). The origins of this segmentation and segment boundary zones are often attributed to the influence of basement structure (e.g., Clemson et al. 1997; Davison 1997). It is thought that such segmentation reflects along-strike changes in the orientation of preexisting structures in the underlying continental basement (McClay and White 1995). A consequence of this model is that if such pre-existing structures undergo reactivation then they will often be significantly oblique to the direction of the later regional extension. This leads to the development of zones of oblique extension or transtension on what would otherwise be a simple extensional margin (Dewey 2002; Morley et al. 2004) and is manifest in the Hun Graben as extension-dominated transtension (figure 9c).

Withjack and Jamison (1986) show that during oblique rifting, the orientation of maximum horizontal extension strain is controlled by $\alpha$, the angle between the rift trend and the direction of displacement. The structural styles and geometries of the Hun Graben resulted from the obliquity between maximum horizontal extensional strain and underlying structural trends led to regional extension of homogeneous transtensional zones with divergence angles $\alpha=51^{\circ}-80^{\circ}$ along the eastern fault zone (EFZ) forming about 30\% normal left strike-slip faults along the western fault zone (WFZ) with divergence angles $\alpha=11^{\circ}-40^{\circ}$. Transtension is defined by $0^{\circ}<\alpha<90^{\circ}$, where pure shear coaxial extension $\alpha=90^{\circ}$ and noncoaxial wrench simple shear $\alpha=0^{\circ}$ and extension-dominated transtension $20^{\circ}<\alpha<90^{\circ}$ (De Paola et al. 2005a).

\subsection{Geometry and kinematic model for NW Libya and the Hun Graben, western Sirt Basin}

The Jifarah Basin (figure 4) considered as part of the Sabratah-Cyrenaica wrench zone (Anketell and Ghellali 1991) shows evidence for extensional dextral strike-slip faults and represents a downfaulted terrace on the boundary between the relatively stable shelf to the south and the unstable continental margin to the north. The Jifarah dextral strike-slip faults underlie the Jifarah Basin and extend westwards into southern Tunisia.

The Jifarah Basin has undergone a complex and polyphase structural history since Carboniferous times (Burollet and Desfoges 1982; Ben Ayed 1986). It has been affected by multiple episodes 


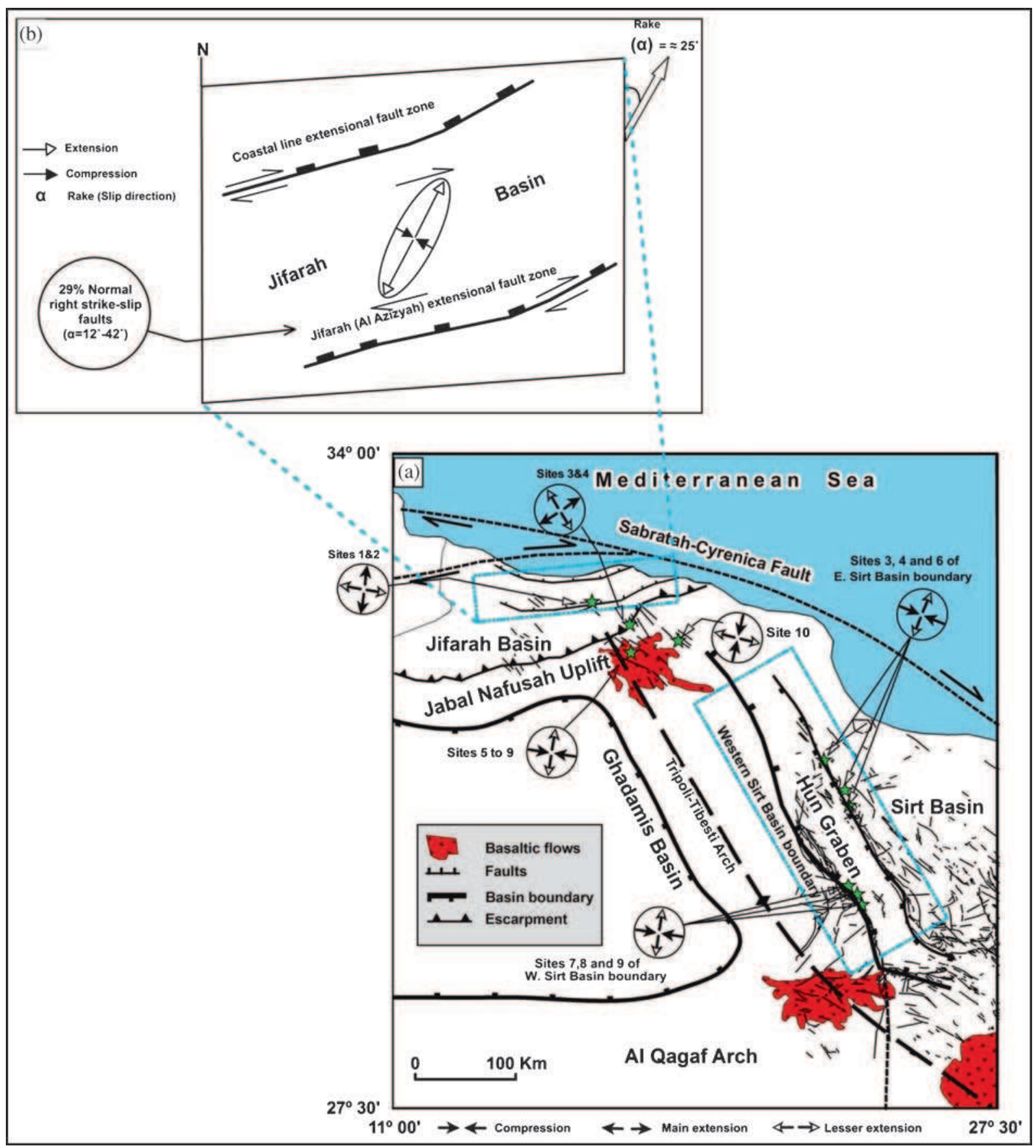

Figure 9. (a) Map shows the location of the study areas and the orientation of maximum horizontal extension of the Jifarah Basin and Jabal Nafusah Uplift. (b) Plan view of structural styles and geometries of associated minor structures of the Jifarah Basin and summarizing corrections due to obliquity between maximum horizontal extensional strain and Jifarah Basin extensional fault zone trends in order to estimate true regional extension. It shows the homogeneous transtension zones with divergence angles $\alpha=25^{\circ}$ and about $29 \%$ are normal right strike-slip faults in the Jifarah Basin with divergence angles $\alpha=12^{\circ}-42^{\circ}$. (c) Plan view of structural styles and geometries of associated minor structures of Hun Graben and summarizing corrections due to obliquity between maximum horizontal extension strain and Hun Graben margin trends in order to estimate true regional extension. It shows the homogeneous transtension zones with divergence angles $\alpha=51^{\circ}$ along the eastern fault zone (EFZ) and about 30\% are normal left strike-slip faults along the western fault zone (WFZ) with divergence angles $\alpha=11^{\circ}-40^{\circ}$. Transtension $\left(0<\alpha<90^{\circ}\right)$ where pure shear coaxial extension $\left(\alpha=90^{\circ}\right)$ and noncoaxial wrench simple shear $\left(\alpha=0^{\circ}\right)$ and extension-dominated transtension $\left(20^{\circ}<\alpha<90^{\circ}\right.$ ) (modified from De Paola et al. 2005a). Note: Withjack and Jamison (1986) show that during oblique rifting, the orientation of maximum horizontal extension strain is controlled by $\alpha$, the angle between the rift trend and the direction of displacement.

of tectonism, including a Late Paleozoic collision with Laurasia and subsequent Early Mesozoic rifting associated with the opening of the Tethyan
Ocean (Memmi et al. 1986; Gabtni 2006). The combined effect of several tectonic phases (Taconic, Caledonian, Hercynian, Austrian and Alpine (Late 


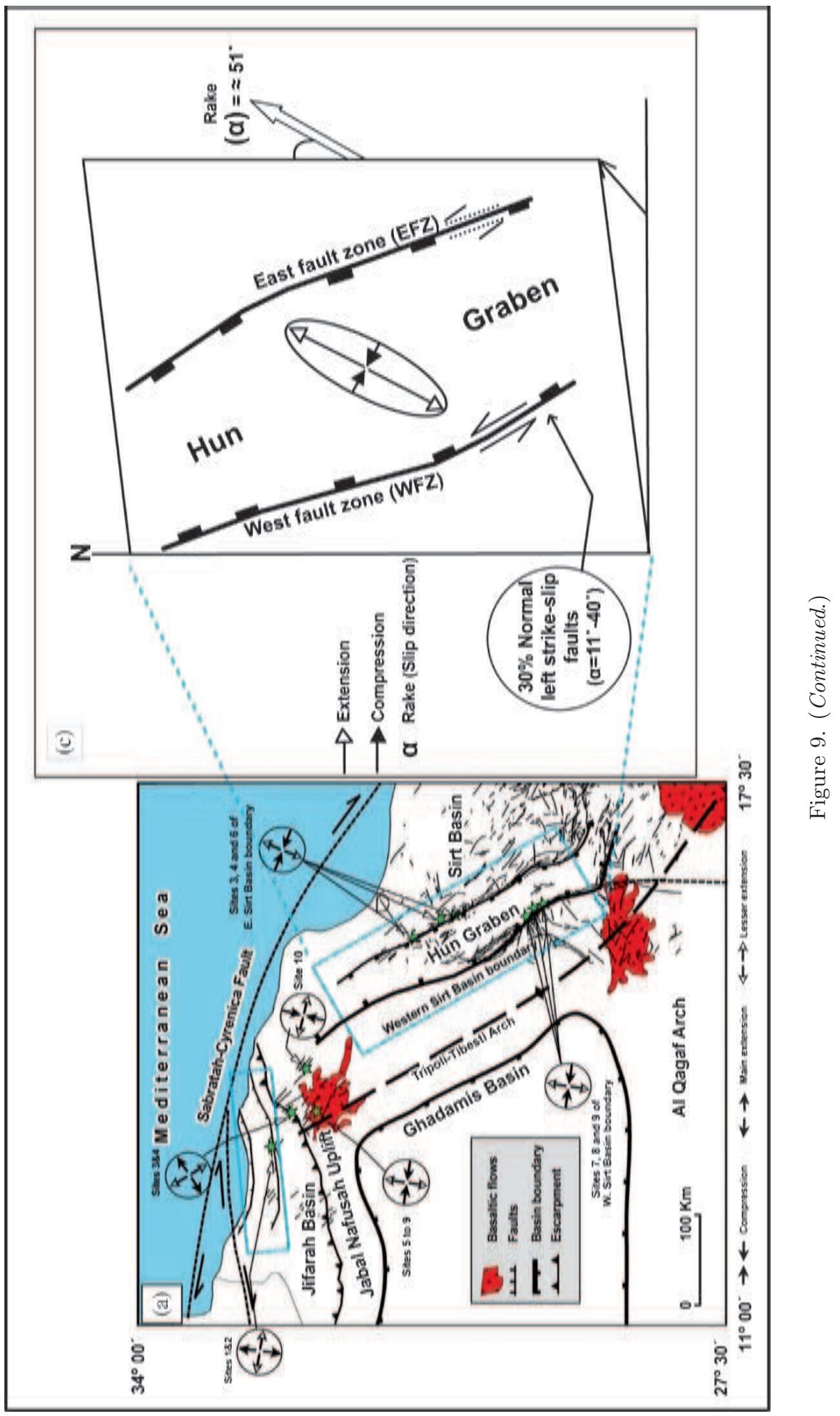


Cretaceous-Early Eocene)) on the Jifarah area has been the production of a large sedimentary basin (Jifarah Basin).

The Mesozoic basin-fill of the Jifarah Basin was affected by normal faulting during the Triassic that is NW-SE-trending (figure 4), in Tunisia, to $\mathrm{E}-\mathrm{W}$-trending, in Libya. A collapsed block faulting formed during the Late Cretaceous and Cenozoic by extensional faulting, is overlain by tertiary and quaternary sediments (Benton et al. 2000).

Anketell and Ghellali (1991) demonstrated that the dominant fault directions in the Mesozoic section in this area are east-west and NNW-ESE with an en echelon arrangement which they interpreted as riedel shears and imbricate fan splays formed as a result of strike-slip movement on the south Atlas-Jifarah dislocation. This direction played a major role during the Cretaceous-Paleocene development of the Sirt Basin, which is characterized by a NE-SW direction of extension (Jongsma et al. 1985; Klett 2001). However, the Jifarah fault system is inherited from a long history and is likely to have acted as a transform direction during the lower Mesozoic (Burollet 1991; Piqué et al. 2002; Lazzez et al. 2008). The Jifarah fault which borders the Jabal Nafusah Uplift from the north was reactivated during the mid-Tertiary in response to the closing of Tethys (Memmi et al. 1986; Gabtni 2006) accompanied by production of basaltic sills and flows near Gharyan formed by Eocene tectonism, and this volcanic activity has continued until recent times.

In Sirt Basin, after initial Cretaceous rifting, major subsidence was achieved in the Paleocene under shallow marine conditions that lasted until the Late Eocene (Goudarzi 1980; van der Meer and Cloetingh 1993; Anketell 1996; Baird et al. 1996; Guiraud and Bosworth 1997; Abdunaser and McCaffrey 2014). Subsidence occurred during Paleogene-Neogene deformation which reactivated the Hun Graben buried structures, as indicated by the close distribution around the $\mathrm{N} 140^{\circ} \mathrm{E}$ trend in Paleogene rocks north of $\mathrm{Bu}$ Njem (Capitanio et al. 2012).

A new kinematic and structural conceptual model is proposed here for the evolution of NW Libya (Jifarah Basin and the Nafusah Uplift) and Hun Graben (figure 9). It seems that the Al Aziziah $\mathrm{E}-\mathrm{W}$ fault system is part of inherited fault system that plays a major role controlling the north tilting of the Jifarah block faulting as well as its sedimentary infilling. In the new structural hypothesis, the Jifarah Basin of NW Libya is interpreted as resulting from large scale block extensional faulting, mainly controlled by inherited $\mathrm{E}-\mathrm{W}$ major faults, the Al Aziziah fault system. This rifting occurred during the Late Triassic up to the end of the Early Jurassic, as part of a general East
Mediterranean block tilting which has been mainly active during the Late Triassic and Lower Jurassic (Raulin et al. 2011). The Hun Graben fault system which resulted from the reactivated Cretaceous faults running in NW-SE direction under similar compressional stress formed the sinistral strike-slip and normal fault movements as shown in figure 9(c). The results show the effects that contrasting pre-existing fault trends (inheritance) can have on the subsequent development and evolution of a continental margin.

\section{Conclusions}

Most of the faults observed in the Hun Graben and northwest Libya (Jifarah Basin and Nafusah Uplift) correspond to minor structures with displacement ranging from several centimetres to several metres. Various types of faults (normal faults, left normal faults, right normal faults and strikeslip faults) with their rake ranging from $51^{\circ}$ to $80^{\circ}$ and their dip ranging from $70^{\circ}$ to $90^{\circ}$ (high-angle normal faults) are present. A NNE-SSW directed extension regime with WNW-ESE compression is recorded by most of the measurements in the study area.

The directions of extension computed from faultslip datasets are remarkably homogeneous in all sites. The WNW-ESE compression and NNESSW extension resulted from this study is consistent with progressive collisional coupling of Africa and Europe, being under approximately WNWESE reactivated compressional stresses during Late Eocene-aged.

In the Hun Graben, about $56 \%$ of the observed faults are predominantly left normal faults (oblique dip-slip component), whilst in northwest Libya (Jifarah Basin and Nafusah Uplift) right normal slip faults represent about $29 \%$ of the total measured faults with a rake ranging between $101^{\circ}$ and $130^{\circ}$ and indicate predominantly NNE-SSW $\left(\mathrm{N} 25^{\circ} \mathrm{E}\right)$ extension and less WNW-ESE $\left(\mathrm{N} 115^{\circ} \mathrm{E}\right)$ compression.

However, $71 \%$ of the observed faults are predominantly normal faults where the compressional regime is restricted mainly on the Jabal Nafusah Uplift area as E-W to WNW-ESE (N95 $\left.{ }^{\circ} \mathrm{E}\right)$ compression along Gharyan fault zone (GFZ), and NNE-SSW $\left(\mathrm{N} 19^{\circ} \mathrm{E}\right)$ compression along Wadi Ghan fault zone (WFZ).

It is clear from this study that the two areas are predominantly characterized by NNE-SSW directions of extension ranging from $\mathrm{N} 12^{\circ} \mathrm{E}$ to $25^{\circ} \mathrm{E}$ with lesser component of ENE-WSW. Therefore, this study suggests that during the Eocene time, the $\mathrm{E}-\mathrm{W}$ faults in the Jifarah Basin underwent a compressional stress trending approximately 
WNW-ESE as a result of the convergence between Africa and Eurasia that began in the Late Cretaceous, about $90 \mathrm{Ma}$ ago which led to the formation of dextral strike-slip movements, whilst the Hun Graben fault system which resulted from the reactivation of Cretaceous faults running in NW-SE direction under similar compressional stress formed the sinistral strike-slip and normal fault movements. Contrasting pre-existing structural trends (Triassic and Cretaceous) clearly influenced the subsequent structural development of NW Libya.

\section{Acknowledgements}

The authors are indebted to the Management of Libyan Petroleum Institute and National Oil Corporation, Libya for their support throughout the study and funding, and the permission to publish this paper. They also would like to extend their thanks to Abdulbasset Abadi and Laila Gamberlu for allowing us to use their own measured fault-slip data. The authors are grateful to Durham University for providing the paleostress analysis software MyFault $^{\mathrm{TM}}$ (v. 1.03). KM thanks the Royal Society for an Industry Fellowship Grant.

\section{References}

Abadi A M 2002 Tectonics of the Sirt basin. Inferences from tectonic subsidence analysis, stress inversion and gravity modelling; PhD thesis, Vrije University, Amsterdam, The Netherlands, 187p.

Abadi A M, van Wees J D, van Dijk P M and Cloetingh S A P L 2008 Tectonics and subsidence evolution of the Sirt Basin, Libya; Am. Assoc. Petrol. Geol. Bull. 92 993-1027.

Abdshakoor A and Shagroni Y 1984 Sheet Hun (NH 33-11), Geological Map of Libya, scale 1:250,000, Explanatory Booklet, Industrial Research Centre, Tripoli.

Abdunaser K M 2012 Structural style and tectonic evolution of the northwest Sirt Basin-Cretaceous-Tertiary Rift, Libya; PhD thesis, Durham University, UK, 260p.

Abdunaser K M and McCaffrey K J W 2014 Rift architecture and evolution: The Sirt Basin, Libya: The influence of basement fabrics and oblique tectonics; J. African Earth Sci. 100 203-226.

Abdunaser K M and Reeh G B 2007 Integration of remote sensing and geophysical data: A case study of structural development and petroleum prospectively of western Sirt Basin, Libya; Petrol. Res. J. 20 45-58.

Anderson E M 1951 The dynamics of faulting and dyke formation with application to Britain; Oliver Boyd, Edinburgh, 260p.

Angelier J 1984 Tectonic analysis of fault slip data sets; J. Geophys. Res. 89(B7) 5835-5848.

Angelier J 1989 From orientation to magnitudes in paleostresses determinations using fault slip data; J. Struct. Geol. 11 37-50.

Anketell J M 1996 Structural history of the Sirt Basin and its relationships to the Sabratah Basin and Cyrenaican Platform, northern Libya; In: The Geology of Sirt Basin (eds)
Salem M J, El-Hawat A S and Sbeta A M (Amsterdam: Elsevier) 2 57-87.

Anketell J M and Ghellali S 1991 A paleogeologic map of the pre-Tertiary surface in the region of the Jifarah Plain and its implication to the structural history of the northern Libya; In: The Geology of Libya (eds) Salem M J, Sbeta A M and Bakbak M R, VI 2381-2406.

Baird D W, Aburawi R M and Bailey N J L 1996 Geohistory and petroleum in the central Sirt Basin; In: The Geology of the Sirt Basin (eds) Salem M J, Busrewil M T, Misallati A A and Sola M A, Elsevier, Amsterdam, 3 3-56.

Ben Ayed N 1986 Evolution tectonique de l'avant pays de la chaîne alpine de Tunisie du début du Mésozoïque a' l'Actuel; Thèse Doc. Etat, Univ. Paris Sud, France, $328 \mathrm{p}$.

Benton M, Bouaziz S, Buffetaut E, Martill D, Ouaja M, Soussi M and Trueman C 2000 Dinosaurs and other fossil vertebrates from fluvial deposits in the Lower Cretaceous of southern Tunisia; Paleogr. Palaeoclim. Palaeoecol. 157 $227-246$.

Bosworth W, El-Hawat A S, Helgeson D E and Burke K 2008 Cyrenaican 'shock absorber' and associated inversion strain shadow in the collision zone of NE Africa; Geology 36 695-698.

Bott M H P 1959 The mechanics of oblique-slip faulting; Geol. Mag. 96 109-117.

Burollet P F 1991 Structures and tectonics of Tunisia; Tectonophys. 195 359-369.

Burollet P F and Desfoges G 1982 Dynamique des bassins néocrétacés en Tunisie in Livre Jubilaire Gabriel Lucas; Mém. Géol. Univ. Dijon, pp. 381-389.

Capitanio F A, Faccenna C and Funiciello R 2009 Opening of Sirte Basin: Result of slab avalanche? Earth Planet. Sci. Lett. 285 210-216.

Capitanio F A, Faccenna C, Funiciello R and Salvini F 2012 Recent tectonics of Tripolitania, Libya: An intraplate record of Mediterranean subduction; Geol. Soc. London, Spec. Publ. 357 319-328.

Cepek P 1979 Sheet Al Qaryat ash Sharqiyah (NH 33-6), Geological map of Libya, scale 1:250,000, Explanatory Booklet, Industrial Research Centre, Tripoli.

Clemson J, Cartwright J and Booth J 1997 Structural segmentation and the influence of basement structure on the Namibian passive margin; J. Geol. Soc. London 154 477-482.

Clifton A E, Schlische R W, Withjack M O and Ackermann R V 2000 Influence on rift obliquity on fault-population systematics: Results of experimental clay models; J. Struct. Geol. 22 1491-1509.

Cloetingh S, Ziegler P A, Beekman F, Andriessen P A M, Matenco L, Bada G, Garcia-Castellanos D, Hardebol N, Dezes P and Sokoutis D 2005 Lithospheric memory, state of stress and rheology: Neotectonic controls on Europe's intraplate continental topography; Quat. Sci. Rev. 24 241-304.

Cvetković V, Toljić M, Ammar N A, Rundić L and Trish K B 2010 Petrogenesis of the eastern part of the Al Haruj basalts (Libya); J. African Sci. 58 37-50.

Davison I 1997 Wide and narrow margins of the Brazilian south Atlantic; J. Geol. Soc. London 154 471-476.

De Paola N, Holdsworth R E and McCaffrey K J W 2005a The influence of lithology and pre-existing structures on reservoir-scale faulting patterns in transtensional rift zones; J. Geol. Soc. London 162 471-480.

De Paola N, Holdsworth R E, McCaffrey K J W and Barchi M R 2005b Partitioned transtension: An alternative to basin inversion models; J. Struct. Geol. 27 607625 . 
De Paola N, Mirabella F, Barchi M R and Burchielli F 2006 Early orogenic normal faults and their reactivation during thrust belt evolution: The Gubbio Fault case study, Umbria-Marche Apennines (Italy); J. Struct. Geol. 28(11) 1948-1957.

Delvaux D, Moeys R, Stapel G, Petit C, Levi K, Miroshnichenko A, Ruzchich V and San'kov V 1997 Paleostress reconstructions and geodynamics of the Baikal region, Central Asia, Part 2. Cenozoic rifting; Tectonophys. 282 1-38.

Dercourt J and Zonenshain L P et al. 1986 Geological evolution of the Tethys belt from the Atlantic to the Pamirs since the Lias; Tectonophys. 123 241-315.

Dewey J F 2002 Transtension in arcs and orogens; Int. Geol. Rev. 44 402-439.

Dewey J F and Burke K C A 1973 Tibetan, Variscan and Precambrian basement reactivation: Products of continental collision; J. Geol. 81 683-692.

El-Hinnawy M and Cheshitev G 1975 Sheet Tarabulus (NI 33-13), Geological map of Libya, scale 1:250, 000, Explanatory Booklet, Industrial Research Centre, Tripoli.

Faccenna C, Jolivet L, Piromallo C and Morelli A 2003 Subduction and the depth of convection in the Mediterranean mantle; J. Geophys. Res. 108, doi: 10.1029/2001JB001690.

Fodor L, Turki S M, Dalob H and Al-Gerbi A 2005 Faultrelated folds and along-dip segmentation of breaching faults: Syn-diagenetic deformation in the southwestern Sirt Basin, Libya; Terra Nova 17(2) 121-128.

Fry N 1999 Striated faults: Visual appreciation of their constraint on possible paleostress tensors; J. Struct. Geol. 21 $7-21$.

Gabtni H 2006 Caractérisation profonde et modélisation géophysique des zones de transition entre les différents blocs structurauxde la Tunisie centro-méridionale; $\mathrm{PhD}$ Thesis, University Tunis El Manar, 243p.

Gamberlu L 2007 Regional analysis of Jifarah Basin using remote sensing and GIS techniques; Unpublished MSc Thesis, Greenwich University, 120p.

Goudarzi G H 1980 Structure-Libya; In: The Geology of Libya (eds) Salem M J and Busrewil, Academic Press, London, III 879-891.

Goudarzi G and Smith J P 1978 Preliminary structure contour map of the Libyan Arab Republic and adjacent areas; 1:2.000,000. US Geological Survey, Miscellaneous Geology Investigation $M A P, \mathrm{I}-350 \mathrm{C}$.

Gray C 1971 Structure and origin of the Gharian domes; First symposium on the geology of Libya (ed.) Gray C, Faculty of Science, University of Libya, Tripoli, pp. 310319.

Guiraud R and Bosworth W 1997 Senonian basin inversion and rejuvenation of rifting in Africa and Arabia: Synthesis and implications to plate-scale tectonics; Tectonophys. 282 39-82.

Guiraud R, Issawi B and Bosworth W 2001 Phanerozic history of Egypt and surrounding areas; In: Peri-Tethys Memoir 6: Peri-Tethyan Rift/Wrench Basins and Passive Margins (eds) Ziegler P A, Cavazza W, Robertson A H F and Crasquin-Soleau S, Mémoires du Muséum national d_Histoire naturelle de Paris 186 469-509.

Gumati Y D and Schamel S 1988 Thermal maturation history of the Sirt Basin, Libya; J. Petrol. Geol. 11 205-218.

Hardcastle K C 1989 Possible paleostress tensor configurations derived from fault-slip data in eastern Vermont and western New Hampshire; Tectonics 8 265-284.

Jongsma D, van Hinte J E and Woodside J M 1985 Geologic structure and neotectonics of the north African continental margin south of Sicily; Marine Petrol. Geol. 2 $156-178$.

Klett T R 2001 Total petroleum systems of the Triassic/ Ghadames province, Algeria, Tunisia, and Libya The Tenezzuft-Oyed Mya, Tanezzuft-Melrhir and Tenezzuft-Ghadames; US Geol. Surv. Bull. 2202-C, 22.

Klitzsch E 1970 Die Die Structurgeschichte der Zentralsahara: Neue Erkenntnissezum Bau und der Palaeogeographieeines Tafellandes; Geologische Rundschau 59(2) $459-527$.

Lazzez M, Zouaghi T and Ben Youssef M 2008 Austrian phase on the northern African margin inferred from sequence stratigraphy and sedimentary records in southern Tunisia (Chotts and Djeffara areas); Tectonics $\mathbf{3 4 0}$ 543-552.

Mandl G 1988 Mechanics of Tectonic Faulting: Models and Basic Concepts; Elsevier, Amsterdam.

Marović M 2007 Structural Setting; In: Geological map of Libya 1:250,000. Sheet Wadi Blhashim (NG 34-1). Explanatory Booklet (eds) Toljić M and Turki S, Industrial Research Center, Tripoli, pp. 109-121.

McClay K R and White M 1995 Analogue models of orthogonal and oblique rifting; Marine Petrol. Geol. 12 137151.

Memmi L, Burollet P F and Viterbo I 1986 Lexique stratigraphique de la Tunisie, première partie: Précambrien et Paléozoïque; Notes du Service Géologique (Tunisie), 53 $64 \mathrm{p}$.

Morley C K, Haranya C, Phoosongsee W, Pongwapee S, Kornsawan A and Wonganan N 2004 Activation of rift oblique and parallel pre-existing fabrics during extension and their effect on deformation style: Examples from the rifts of Thailand; J. Struct. Geol. 26 18031829 .

Peregi Zs, Less Gy, Konrád Gy, Fodor L, Gulácsi Z, Gyalog L, Turki S M, Suwesi S K H, Sherif K and Dalub H 2003 Geological map of Libya 1:250,000. Sheet Al Haruj al Abyad (NG 33-8); Explanatory Booklet, Industrial Research Center, Tripoli, 250p.

Piqué A, Tricart Guiraud P, Laville R E, Bouaziz S, Amrhar S M and Aït Ouali R 2002 The MesozoicCenozoic Atlas belt (north Africa); Geodyn. Acta 15 159208.

Price N J 1966 Fault and Joint Development in Brittle and Semi-brittle Rock; Pergamon, London.

Raulin C, de Lamotte D F, Bouaziz S, Khomsi S, Mouchot N, Ruiz G and Guillocheau F 2011 Late Triassic-Early Jurassic block tilting along $\mathrm{E}-\mathrm{W}$ faults, in southern Tunisia: New interpretation of the Tebaga of Medenine; J. African Earth Sci. 61 94-104.

Robertson A H F and Dixon J E 1984 Aspects of the geological evolution of the eastern Mediterranean; In: The Geologic Evolution of the Eastern Mediterranean (eds) Dixon J E and Robertson A H, Geol. Soc. London, Spec. Publ. 17 1-74.

Schäfer K, Kraft K H, Hausler H and Erdman J 1980 In situ stresses and paleostresses in Libya; In: Geology of Libya (eds) Salem N J and Busrewil M T, Al-Fateh Univ, Tripoli, pp. 907-922.

Shan Y, Li Z and Lin G 2004a A stress inversion procedure for automated recognition of polyphase fault/slip data sets; J. Struct. Geol. 26(9) 919-925.

Suleiman A S and Doser D I 1995 The seismicity, seismotectonics and earthquake hazards of Libya, with detailed analysis of the 1935 April 19, $M=7.1$ earthquake sequence; Geophys. J. Znt. 120 312-322.

Tawadros E E 2001 Geology of Egypt and Libya; A.A. Balkema, Rotterdam, 468p. 
van der Meer F and Cloetingh S 1993 Intraplate stresses and the subsidence history of the Sirt Basin (Libya); Tectonophys. 226 37-58.

van Houten F B 1983 Sirt Basin, north-central Libya: Cretaceous rifting above a fixed mantle hotspot? Geology $\mathbf{1 1}$ $115-118$.

Voight B 1966 Beziehung zwischen großen horizontalen Spannungen in Gebirge und der Tektonik und der Abtragung; In: Proc. 1st Congr. Int. Soc. Rock Mech., 2 1e56, Lisbon.

Wallace R E 1951 Geometry of shearing stress and relation to faulting; J. Geol. 59 118-130.
Wilson M and Guiraud R 1992 Magmatism and rifting in western and central Africa from Late Jurassic to recent times; Tectonophys. 213 1-23.

Withjack M O and Jamison W R 1986 Deformation produced by oblique rifting; Tectonophys. 126 99-124.

Yamaji A 2000 The multiple inverse method: a new technique to separate stresses from heterogeneous fault-slip data; J. Struct. Geol. 22(4) 441-452.

Ziegler P A, Van Wees J D and Cloetingh S 1998 Mechanical controls on collision-related compressional intraplate deformation; Tectonophys. 300 103-129. 